\title{
Biology, Fishery, Conservation and Management of Indian Ocean Tuna Fisheries
}

\author{
N Gopalakrishna Pillai* and Palanisamy Satheeshkumar \\ Central Marine Fisheries Research Institute, Cochin 682018, Kerala, India
}

Received 10 May 2012; Revised 14 October 2012; Accepted 3 December 2012

(C) KSO, KIOST and Springer 2012

\begin{abstract}
The focus of the study is to explore the recent trend of the world tuna fishery with special reference to the Indian Ocean tuna fisheries and its conservation and sustainable management. In the Indian Ocean, tuna catches have increased rapidly from about $179959 \mathrm{t}$ in 1980 to about $832246 \mathrm{t}$ in 1995 . They have continued to increase up to 2005; the catch that year was 1201465 $t$, forming about $26 \%$ of the world catch. Since 2006 onwards there has been a decline in the volume of catches and in 2008 the catch was only 913625 t. The Principal species caught in the Indian Ocean are skipjack and yellowfin. Western Indian Ocean contributed $78.2 \%$ and eastern Indian Ocean $21.8 \%$ of the total tuna production from the Indian Ocean. The Indian Ocean stock is currently overfished and IOTC has made some recommendations for management regulations aimed at sustaining the tuna stock. Fishing operations can cause ecological impacts of different types: by catches, damage of the habitat, mortalities caused by lost or discarded gear, pollution, generation of marine debris, etc. Periodic reassessment of the tuna potential is also required with adequate inputs from exploratory surveys as well as commercial landings and this may prevent any unsustainable trends in the development of the tuna fishing industry in the Indian Ocean.
\end{abstract}

Key words - conservation, fisheries, management, ocean ecosystem, recruitment, tuna

\section{Introduction}

Tunas are widely distributed throughout the world and generally they occur in temperate to tropical waters between about $45^{\circ}$ north and south of the equator and are broadly classified into coastal, neritic and oceanic species. They are grouped taxonomically in the family Scrombridae, which consists of about 50 species, and forms the third largest

\footnotetext{
*Corresponding author. E-mail: gopalji2@rediffmail.com, tunaieez@gmail.com
}

product in the international seafood trade with almost $10 \%$ of the total trade in value terms (FAO 2008). The principal market species of tuna are skipjack (Katsuwonus pelamis), yellowfin (Thunnus albacare), bigeye (T. obesus), albacore (T. alalunga), Northern bluefin (T. thynnus) and Southern bluefin (T. maccoyii). Furthermore, as fisheries give direct employment to about 200 million people (FAO 1993), and account for $19 \%$ of the total human consumption of animal protein (Botsford et al. 1997), the decline or collapse of these species has the potential to have drastic social and economic consequences in some fisheries dependent regions of the globe. It is surprising that while these ecologically and economically important species continue to decline, large scale patterns of abundance and diversity that are so essential to effective conservation are relatively poorly understood. This is in part explained by the fact that tuna and billfish are highly migratory species usually found many miles offshore, making information-gathering expensive and time-consuming. Consequently, most of the information on these species comes from exploited fisheries data, which may be biased, inaccurate or lacking in quality. The issue is compounded by under- and over reporting of catches by countries reporting to the Food and Agriculture Organization (FAO) of the United Nations, the institution charged with recording global fisheries statistics (Watson and Pauly 2001). Although knowledge of global distribution patterns of each species of tuna and billfish have rapidly advanced in recent years, through tagging studies (Block et al. 2001), community-wide patterns of abundance and richness remain poorly understood (Worm et al. 2005).

Scientific advice on fisheries management is generally based on the results of the application of some stock assessment 
techniques (Hilborn and Walters 1992). Stock assessment usually involves estimating the limits of some form of population dynamics model by fitting it to research and monitoring data and using the results of the fitting process to estimate quantities (such as the current abundance) that are of interest to decision makers (Maunder et al. 2004). Temperature and food availability are reported to influence their distribution and abundance. Tuna shows distinct migratory routes, spawning, and feeding locations (Block et al. 2001). Tunas are fast swimmers and capable of travelling more than $48 \mathrm{~km} / \mathrm{hr}$. As a result of increasing demand for tunas for canning, industrial fisheries started during the 1940s and 1950s and the global catch reached 3.5 million tonnes (mt) in 1997 to further increase to $4.3 \mathrm{mt}$ during 2005. Tuna catching nations are mainly concentrated in Asia with Japan, Taiwan, Indonesia and South Korea the principals.

Globally, many tuna stocks are under severe threat. For example, the World Conservation Union (IUCN) lists the western Atlantic Ocean stock of Atlantic Bluefin Tuna $T$. thynnus and the Southern Bluefin tuna T. macoyii stock as critically endangered and the eastern Atlantic Ocean stock of Atlantic Bluefin tuna, bigeye and albacore as endangered (IUCN 2011). While demand for high value seafood such as bluefin, skipjack, yellowfin and bigeye tuna continues to grow there is also an increasing awareness in the community generally, and by seafood consumers specifically, of the need for sustainable fisheries and marine ecosystems. Responsibility for ensuring this sustainability falls jointly on those who rely on fisheries for their livelihood, on national and regional management authorities and on consumers. Global demand for fish is exerting more pressure on fish stocks, in addition to climate change induced impacts (Cheung et al. 2009).

Large pelagic fish resources are widely distributed throughout the Indian Ocean (Stequert and Marsac 1989). Tunas and billfish are considered to be highly migratory species, as demonstrated by tagging. Most species of tuna can migrate over long distances (Jones et al. 1999), but recent data would suggest that large-scale movements are not always common (Hampton and Gunn 1998). Tuna catches across the Indian Ocean have fallen sharply in the last two years (2009-2010) but experts are split over what is threatening the regions $\$ 6$ billion industry (Pillai 2010). Conservationists blame the industry for years of unchecked exploitation while processors say climatic conditions may be driving the fish to deeper waters away from their nets
(Polacheck 2006). Overexploitation of bycatch and target species of marine capture fisheries is the most widespread and direct driver of change and loss of global marine biodiversity. Bycatch in purse seine and pelagic longline tuna fisheries, the two primary gear types for catching tunas, is a primary mortality source of some populations of seabirds, sea turtles, marine mammals and sharks (Gilman 2011).

This paper provides an overview of the fishery, biology, distribution and biological reference points for tuna species in the Indian Ocean. It traces the history of scientific advice and management of tuna, and examines the current status of tuna stocks and new areas for tuna fisheries research and developments. In addition to contributing to ecological sustainability this will, ultimately, give a platform from which tuna fisheries can seek Marine Stewardship Council (MSC) certification and take advantage of the growing consumer awareness and demand for sustainably-produced seafood.

\section{Database}

Global tuna catch data were retrieved from the website of Food and Agriculture Organization (http://www.fao.org/ fishery/statistics/tuna-catches/en). Nominal catch data of tuna from Indian Ocean and India were also collected from the Indian Ocean Tuna Commission (http://www.iotc.org/ English/data.php).

\section{Recent Trends in Global Tuna Production}

World tuna fisheries are reviewed in terms of commercially important species, by ocean and by major fishing gear types. Tuna and tuna-like species are very important economically and are a significant source of protein food. Their global production has tended to increase continuously from less than $0.6 \mathrm{mt}$ in 1950 to above $4.5 \mathrm{mt}$ in 2008 (FAO 2009). They are landed in many locations around the world, traded on a nearly global scale and processed and consumed in many locations worldwide. The global tuna production increased significantly from 1962 onwards with minor fluctuations and that pole and line catch also exhibited a similar stabilized production from 1972 onwards. Generally, tuna catches have had an uncertain pattern - flat, or in some cases decreasing. However, between 1997 and 1999 catches increased by about 19\% due to an abundance of skipjack, especially in the Pacific Ocean. Between 1995 and 1996, catches stayed relatively steady - between 3.2 and $3.3 \mathrm{mt}$. In 1997, the catch reached $3.4 \mathrm{mt}$, and continued to 


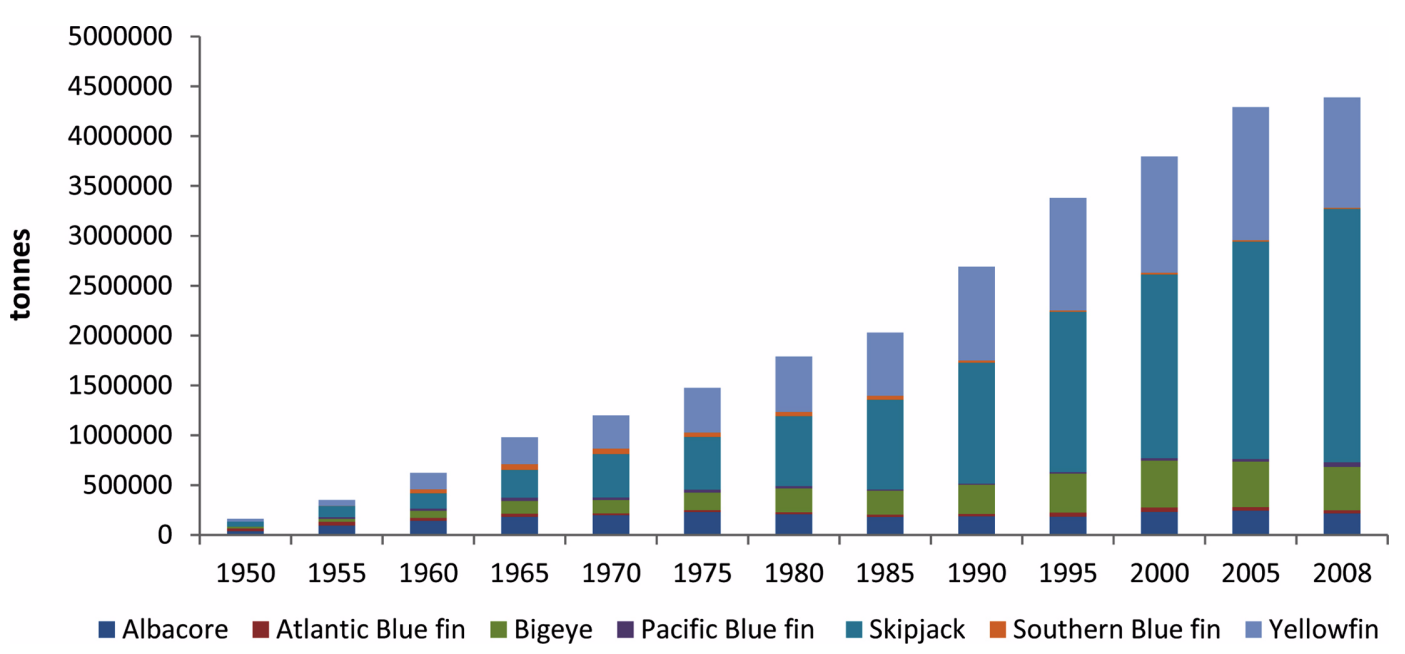

Fig. 1. Trends in world species-wise tuna catch during 1950-2008

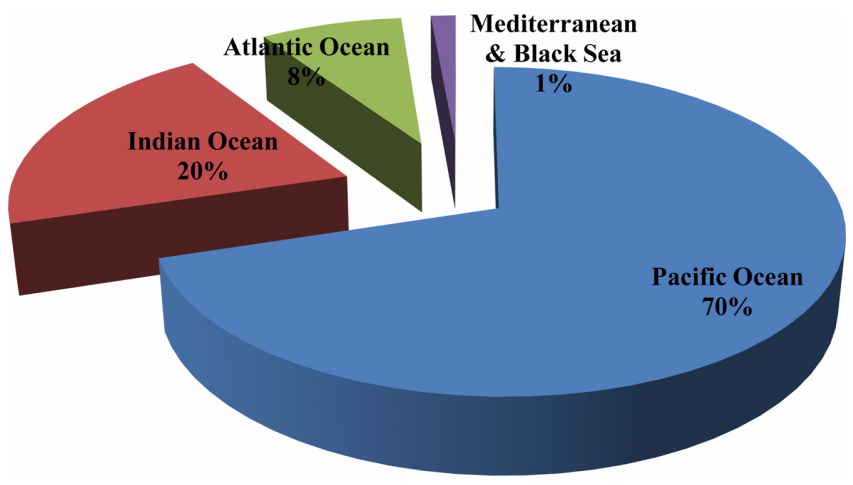

Fig. 2. Ocean-wise tuna production

increase through 1999 to $3.9 \mathrm{mt}$. It slightly decreased to $3.6 \mathrm{mt}$ in 2000. In 2008, catch was recorded at $4.5 \mathrm{mt}$, which represents $67 \%$ of the total catch of all tuna and tuna-like species (Fig. 1). Most catches of the principal market tuna species in 2008 were caught from the Pacific (70.2\%) followed by Indian Ocean which is contributing much more $(20.4 \%)$ than the Atlantic $(8.0 \%)$ and the Mediterranean Sea (1.4\%) (Fig. 2).

\section{Species composition}

More than 12 species belonging to six genera support tuna fishery in the world. The species composition of tuna catches by different gears indicate that skipjack $K$. pelamis was the dominant species followed by yellowfin $T$. albacares, bigeye T. obesus, albacore T. alalunga and remaining other tuna species. The percentage composition of different species indicates that the catch was dominated by skipjack constituting $58 \%$ followed by yellowfin $25 \%$, bigeye $10 \%$, albacore $5 \%$ and remaining other tunas (Fig. 3).

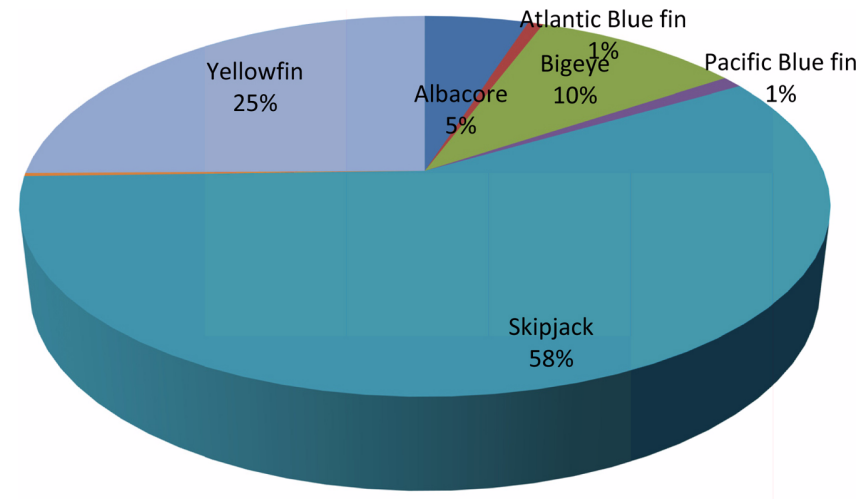

Fig. 3. Species composition of world tuna production during 2008

\section{Gear wise production}

Drift gillnet with mesh size $60-160 \mathrm{~mm}$, hooks and line, purse seine, troll line, long line and pole and line are mainly employed for the exploitation of tuna. The tuna production of different types of fishing fleet under the mechanized sector in 2008 was dominated by purse seine $63 \%$, followed by longline $13 \%$, other gears $12 \%$, pole and line $10 \%$ and troll line $2 \%$. Purse seine vessels, which catch primarily skipjack and yellowfin, average about $60-75 \mathrm{~cm}$ in length, and can carry 1 to 2 thousand tonnes of frozen tuna in their storage wells, are responsible for about $63 \%$ of all tuna captured, with most of this catch destined for the canned tuna market. About $13 \%$ of the world production of tuna caught with longlines, which consists of a mainline, kept a float with buoys, from which branch lines are suspended, each with a hook attached to the end. Longline gear is considered a passive fishing gear, but selecting the area and depth at which hooks are set can increase the probability of 
capturing certain species. Much of the catch of longliners is destined for the higher priced sashimi trade. The Japanese vessels have historically accounted for most of the longline catches, followed by vessels from Taiwan, South Korea and Indonesia. Prior to 1960, most of the world's tuna fleet was comprised of pole and line vessels, which use live bait to attract tuna, which are then caught with hooks and lines attached to the end of a pole. Currently, pole and line fishing account for about $10 \%$ of the world production of tuna (IOTC 2010). It is very important to closely monitor the exploitation of tuna by different gears to avoid over exploitation and over capitalization and thereby to avoid the collapse of the fishery industry.

\section{Status of the Tuna Fishery in Indian Ocean}

Tuna fishery in the Indian Ocean is fully developed, with several coastal countries as well as distant water fishing nations participating in the fishery industry. In the Indian Ocean, tuna catches increased rapidly from about 237986 tonnes (t) in 1980 to $654754 \mathrm{t}$ in 1995 . They continued to increase up to 2005; the tuna catch in that year was $1318648 \mathrm{t}$, forming about $26 \%$ of the world catch. However, since 2006 onwards there has been a decline in the tuna catch and in 2010 the catch was only $1257908 \mathrm{t}$ (Fig. 4). The catch of bigeye has also increased to around $150000 \mathrm{t}$, due to increased targeting of tunas for the sashimi market by longliners and the use of Fish Aggregating Devices (FADs) in surface fishery. Although the catch of yellowfin tuna increased gradually in the past five decades, its relative importance decreased rapidly. Skipjack constituted about $38 \%$ of the

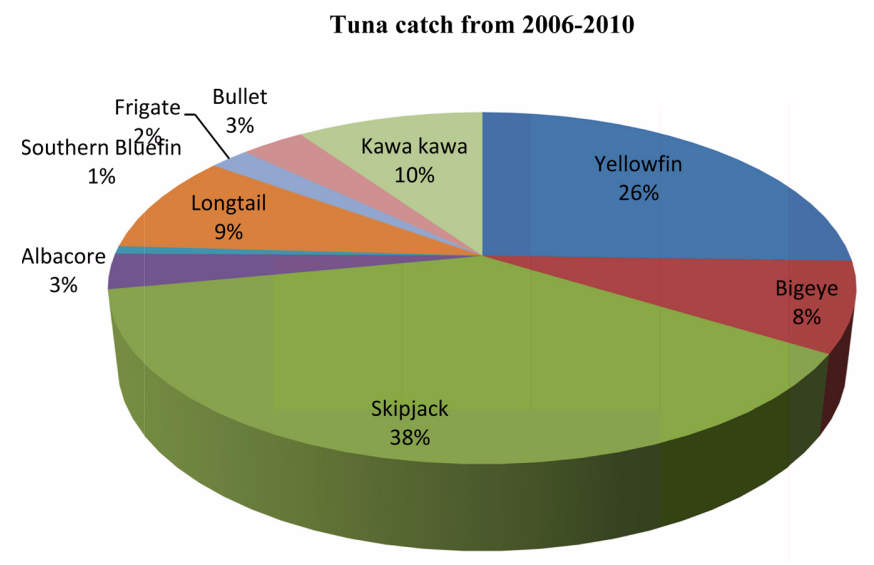

Fig. 5. Species-wise contribution of tuna catch in Indian Ocean from 2006-2010

total catch, yellowfin 26\%, kawakawa 10\%, bigeye $9 \%$, albacore $3 \%$ and blue fin $1 \%$ (Fig. 5). Purse seiners account for about $36 \%$ of the total tuna catch followed by gillnetters $31 \%$, long liners $15 \%$, bait boat $10 \%$, pole and line $7 \%$ and the remaining by a variety of other gears represents $1 \%$, as shown in Fig. 6. Western Indian Ocean contributed 78.2\% and eastern Indian Ocean $21.8 \%$ of the total tuna production from the Indian Ocean.

As many as 67 countries have been involved in tuna fishing in the Indian Ocean; the main tuna catching nations are concentrated in Asia, with Taiwan and Japan the main producers. Other important tuna catching nations are the Philippines, Indonesia, South Korea, Spain and France. In 2008 Indian Ocean tuna production declined to $1148911 \mathrm{t}$ with an estimated landed value of US\$ 2.5 billion. The present decline in production of the Indian Ocean tuna

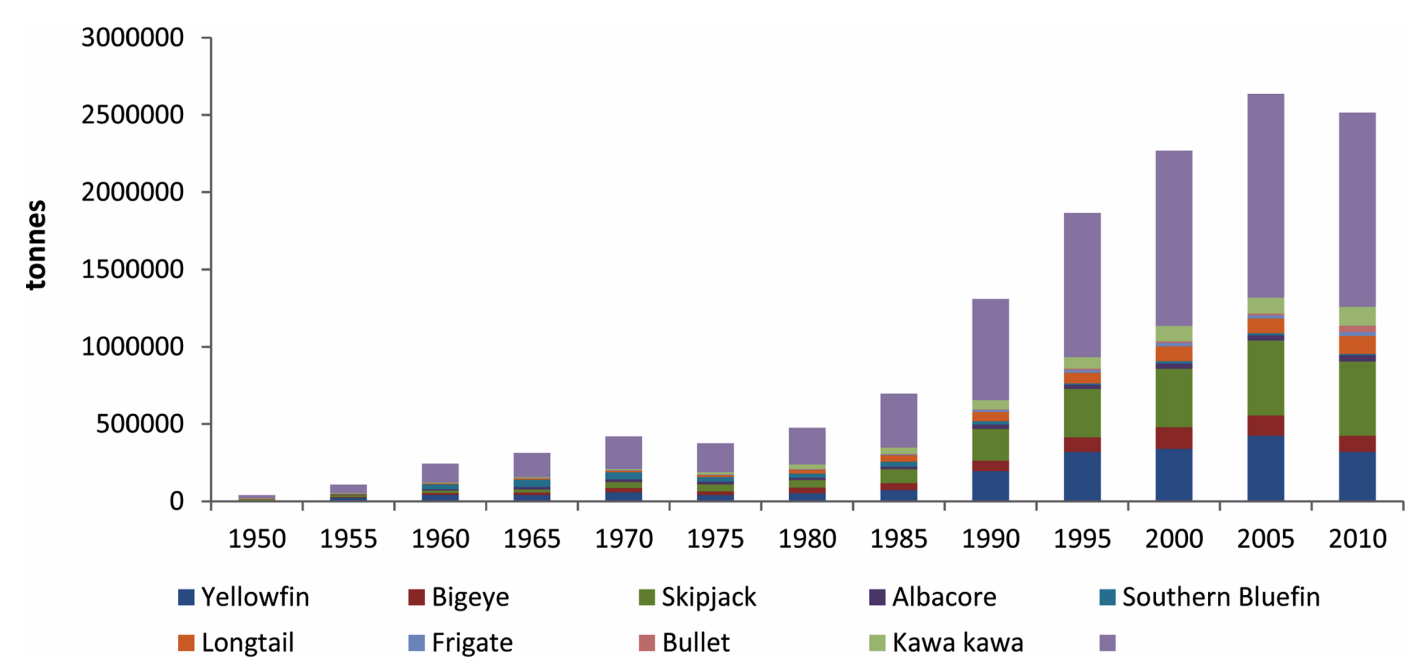

Fig. 4. Recent trends in tuna catch in Indian Ocean from 1950-2010 


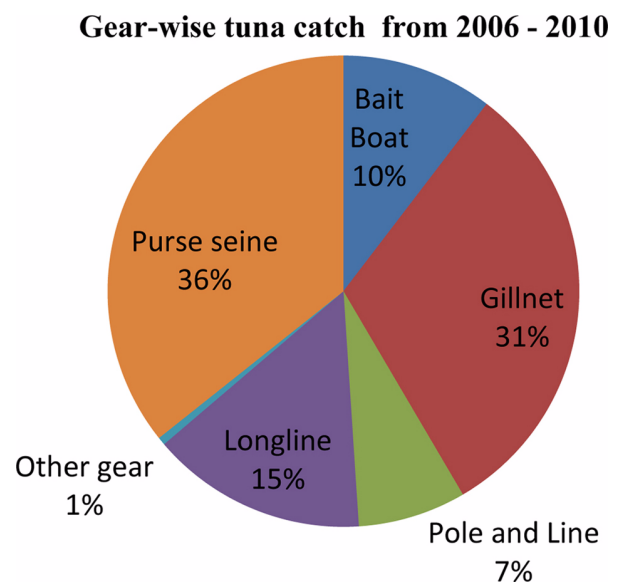

Fig. 6. Gear-wise contribution of tuna catch in Indian Ocean from 2006-2010

fisheries may have serious ecological and socioeconomic consequences. Analysis of landing data clearly indicated that over exploitation of targeted species threatens the sustainability of tuna populations. Though there had been a substantial increase in the production of tunas in the Indian Ocean, the fast pace of development has ignored several patterns which are vital to sustain the tuna production in captured fisheries.

\section{Major tuna stocks in the Indian Ocean \\ Skipjack}

Skipjack has become the most important tuna species in the Indian Ocean in terms of catch and is widely distributed throughout the Indian Ocean Fishing Zone, with the majority of the catch being taken in the Western Indian Ocean. It is a highly productive species and resilient to overfishing. Skipjack tuna is mainly caught by purse seine, gillnet and bait boat - using pole and line. Total annual catches averaged $477859 \mathrm{t}$ over the period 2006 to 2010 . The 2006 catch peaked at $608738 \mathrm{t}$ while the provisional catch estimate for 2010 stands at $429729 \mathrm{t}$ (Fig. 4). The preliminary data for the Indian Ocean suggest that the 2010 catch of skipjack (429729 t) may be the lowest reported since 1998. The decline in the catch rates in the Indian Ocean fishery may be due to higher than average sea - surface temperatures and the marked increase in fuel prices (IOTC 2010).

The development of fishing methods using fish - aggregating devices (FADs) have increased skipjack catches by purse seiners in recent years and $89 \%$ of current (2009) purse seine skipjack catch is taken under natural FADs (log schools). The proportion of catches taken by industrial purse seiners was $(36 \%)$ in 2010 , which was $42 \%$ in 2006 , while the proportion of catches taken by gillnets in the artisanal fisheries has increased (30-34\%). The mean weight from $\log$ school tuna has varied between 2.1 and $3.0 \mathrm{~kg}$ since the 1990s, (average $2.6 \mathrm{~kg}$ ), decreased largely in 2007 and 2008 ( $2 \mathrm{~kg}$ ) before increasing to $2.4 \mathrm{~kg}$ in 2009 , which remains less than the average since 1991. For free schools, the mean weight fluctuated between $3-4 \mathrm{~kg}$ (mean $3.2 \mathrm{~kg}$ ) until 2007, and then dropped markedly to $2.4 \mathrm{~kg}$ in 2009 , the lowest value ever observed.

Table 1 provides a summary of the assessment results of the Indian Ocean tuna stocks. There was a continuous increase in skipjack catches from the mid 1980s until 2006, which has been credited with the expansion of FADassociated fishery in the western Indian Ocean (IOTC 2010). Catch per unit effort on free schools of skipjack tuna is relatively low and remained stable over time, around 2.5t/ sd since 1991. On the other hand, catch rates on log schools increased steadily up to 2002, fluctuated over the period 2003-2006 and then dropped markedly in 2007-2008. Catch by positive set remains in the historical range (19t/set since 1991); this is also the case for log schools (21.9t/set compared to an average of $25.0 \mathrm{t} / \mathrm{set}$ since 1991), while free schools catch by set remains low (6.0t/set compared to an average of $8.7 \mathrm{t} /$ set since 1991). The high productivity and life history characteristic of skipjack tuna suggest this species is

Table 1. Summary of tuna stock status in the Indian Ocean

\begin{tabular}{cccccc}
\hline \hline Stocks & Highest catch & MSY & $\mathrm{B}_{\text {curren }} / \mathrm{B}_{\mathrm{MSY}}$ & $\mathrm{F}_{\text {current }} / \mathrm{F}_{\mathrm{MSY}}$ & Recommendation \\
\hline ALB & $41019 \mathrm{t}(2009)$ & $28260 \mathrm{t}-34415 \mathrm{t}$ & $>1$ & $0.48-0.901$ & No recommendation \\
& $151700 \mathrm{t}(1999)$ & $114000 \mathrm{t}$ & $1.34(1.04-1.64)$ & $0.81(0.54-1.08)$ & Catch $<$ MSY and Effort $<2004$ \\
SKJ & $622600 \mathrm{t}(2006)$ & $\mathrm{NA}$ & Unknown & Unknown & No recommendation \\
YFT & $523600 \mathrm{t}(2004)$ & $320000 \mathrm{t}$ & $1.13-0.93$ & $0.9-1.60$ & TAC and Effort $<2007$ \\
SBF & & $\mathrm{NA}$ & $0.101-0.1272$ & Not reported & TAC \\
SWF & $29900 \mathrm{t}(2008)$ & $33000 \mathrm{t}$ & Not reported & Not reported & None \\
\hline
\end{tabular}

Source: IOTC 2010. MSY; Maximum Sustainable Yield, NA; Not Available, TAC; Total Allowable Catch 
resilient and not easily prone to overfishing. However, the analysis of some indicators of stock status for recent years suggests that the situation of the stock should be closely monitored in 2011 (IOTC 2010). A total of 78326 skipjack were tagged and released mainly off the coast of Tanzania, around Seychelles and the Mozambique Channel. So far 12631 fish (16.1\%) have been recovered and reported, 96\% of them by the European and Seychelles purse seine fleets. Recoveries are well spread in the Indian Ocean and seem to indicate a good mixing of the tagged population with the wild population, and this confirms the one stock hypothesis in the Indian Ocean (IOTC 2010).

\section{Yellowfin}

Yellowfin tuna is mainly caught by purse seine, longline and gillnet fisheries but also by handline and pole and line fleets. The annual total catches averaged $372200 \mathrm{t}$ over the period 2005 to 2009 . Total catches peaked at $523600 \mathrm{t}$ in 2004 and $503700 \mathrm{t}$ in 2005 before decreasing to $291356 \mathrm{t}$ in 2010. They averaged $319856 \mathrm{t}$ over the period 2006 to 2010; catches in 2009 were $268192 \mathrm{t}$ which is the lowest catch since 1991. The location of the fishery has changed little since 1990, yellowfin tuna are fished throughout the Indian Ocean, with the majority of the caches being taken in western equatorial waters. Over $40 \%$ of purse seine yellowfin catches are taken in log associated schools along with skipjack and bigeye tuna. Catches increased since the beginning of fishery, peaked at over $523745 \mathrm{t}$ in 2004 (with very high catches during the period 2003-2006), and then decreased sharply thereafter to $269384 \mathrm{t}$ in 2009 and the 2010 catch slightly increased to $291902 \mathrm{t}$ (Fig. 4). Catch per unit effort follows the catch variations on free schools, with very high values during 2003-2005 (14t/search day compared to an average of 7.2t/search day since 1991), while remaining more or less stable for associated log schools (around 3.2t/ search day up to 1994 , around 5.5 t/search day over the period 1995 to 2006, falling back to the earlier low levels in 2008 of 3.7t/search day before increasing again in 2009 to over $6 \mathrm{t} /$ search day (IOTC 2010). Catch per positive set remained stable at $7 \mathrm{t}$ on logs and $243 \mathrm{t}$ on free schools, except for the high values for 2002-2005.

Mean weight (for all yellowfin tuna caught by purse seiners) fluctuated between 10-20 kg until 1996, and since then it has been between $6-15 \mathrm{~kg}$. Mean weight has remained stable for log caught yellowfin (4-10 kg), with relatively lower levels (4-6 kg) since 1996. Mean weight fluctuates more widely for free school yellowfin (15-32 kg), but it has been relatively stable at high levels since $2002(35-40 \mathrm{~kg})$. Size distribution in 2009 was compared with those observed in the previous periods 2004-2008 and 2006-2008 (the latter being chosen to correct the impact of the large free schools of yellowfin catches in 2003-2005). Log schools catch shows a large number of small yellowfin (less than 80 $\mathrm{cm}$ ), including a second mode shifted towards the larger sizes compared with the previous reference periods, as well in number and in weight. Free school catches also exhibit a very large number of small yellowfin (three times that of the previous period) with two modes, the second one being also largely shifted towards the larger fishes; on the other hand, the amount of large fishes (over $100 \mathrm{~cm}$ ) is lower than that of these reference periods with somewhat bigger fishes (IOTC 2010).

Estimates of total and spawning stock (adult) biomass continue to decline (IOTC 2009), probably accelerated by the high catches of 2003-2006. It appears that overfishing occurred in recent years, and the effect on the standing stock is still noticeable as biomass appears to be decreasing despite catches returning to pre -2003 levels. The MSY has been estimated to be $300,000 \mathrm{t}$, if the steepness of the stock recruitment relationship is assumed to be 0.8 . The preliminary estimate of the 2008 catch (322000 t) is above the current estimate of MSY while annual catches over the period 2003-2006 (averaging 464, 000 t) were sustainably higher than all estimated values of MSY. The current estimate of MSY is $300000 t$, lower than the average catches sustained over the 1992-2002 period of around $343000 \mathrm{t}$. The high catches of the 2003-2006 periods appear to have accelerated the decline of biomass in the stock, which might be currently unable to sustain the 1992-2002 level catches. The stock of yellowfin tuna has recently become overexploited or is very close to being overexploited. Management measures should be continued that allow an appropriate control of fishing pressure to be implemented. It is recommended that annual catches of yellowfin tuna should not exceed the estimated MSY of $300000 t$ and close monitoring and data collection is being strengthened over the coming year in order to know more about the stock situation (IOTC 2011; Majkowski 2005). If recruitment continues to be lower than average, catches below $300000 \mathrm{t}$ would be needed to maintain stock levels.

A total of 54687 yellowfin were tagged and released mainly off the coast of Tanzania but also in the Arabian Sea, 
around Seychelles and in the Mozambique Channel. So far 9739 fish (17.8\%) have been recovered and reported, 93\% of them by the European and Seychelles purse seine fleets. Recoveries are well spread in the Indian Ocean and seem to indicate a good mixing of the tagged population with the wild population, and this confirms the one stock hypothesis in the Indian Ocean (IOTC 2010).

\section{Bigeye tuna}

In contrast with yellowfin and skipjack tunas, for which the major catches take place in the western Indian Ocean, bigeye tuna is also exploited in the eastern Indian Ocean. Their fishing grounds were located from latitude $15^{\circ} \mathrm{N}$ to $6^{\circ} \mathrm{S}$ and longitude $78^{\circ}$ to $96^{\circ} \mathrm{E}$, in the eastern Indian Ocean. Bigeye tuna is mainly caught by industrial purse seine and longline fisheries and appears only occasionally in the catches of other fisheries. However, in recent years the amounts of bigeye tuna caught by gillnet fisheries are likely to be considerably higher due to the major changes experienced in some of these fleets, notably changes in boat size, fishing techniques and fishing grounds. Total annual catches have increased steadily since the start of fishery, reaching the $100,000 \mathrm{t}$ level in 1993 and peaking at $151700 \mathrm{t}$ in 1999. They averaged $108245 \mathrm{t}$ over the period 2006 to 2010 . The 2008 catch was $107975 \mathrm{t}$ and the provisional 2010 catch stands at $80887 \mathrm{t}$. In recent years the catches of bigeye tuna in the western Indian Ocean have dropped considerably, especially in areas off Somalia, Kenya and Tanzania, in particular in 2008 and especially in 2009. The drop in catches is the consequence of a drop in fishing efforts in both purse seine and longline fisheries, due to the effect of piracy in the western Indian Ocean region, while catches are increasing in the eastern Indian Ocean probably due to the shift of some longline fleet in the areas because of piracy activities in the Somalia area.

Around $75 \%$ of purse seine bigeye catches are taken in the log-schools along with skipjack and yellowfin tuna, $80 \%$ of them being less than $5 \mathrm{~kg}$. Catches increased since the beginning of fishery, peaked at over $30000 \mathrm{t}$ from 1997 to 1999 and then stabilized at around 22000 t. During the previous years, an increase in the catches is observed peaking in 2008 and 2009 at 26500 t. However, bigeye catches remains relatively low, representing some $8 \%$ of the total catch since 1991 ( $9 \%$ on logs and $5 \%$ on free schools).The mean weight of bigeye tuna in the purse-seine fishery reflects mainly the log school catches, and remains very stable at around $6 \mathrm{~kg}$. By contrast, free schools set exhibit large variations, remaining high (over $30 \mathrm{~kg}$ ) between 2002 and 2008, and dropping to $17 \mathrm{~kg}$ in 2009. It was noted that this could be due to sampling procedures, and/or from highly variable proportions of small and large bigeye in the catch, and so results should be interpreted with some caution. Size distribution in 2009 was compared with those observed in the previous periods 2004-2008 and 2006-2008 (the latter being chosen to correct the impact of the large free schools of yellowfin catches in 2003-2005). Log schools shows a large number of small bigeye (less than $65 \mathrm{~cm}$ ) in the catches (in number as well as in weight), much higher than during the previous periods. Small bigeye free schools catches were also important and higher than previously in numbers, the larger ones (over $100 \mathrm{~cm}$ ) remaining in the same range; in weight, the pattern is close to the average situations, with a somewhat larger catch of small bigeye.

The results of the stock assessments conducted in 2009 were broadly similar to previous work. The preliminary estimate of catches in 2009 (107000 $t$ ) and catch dropped in $2010(80887 \mathrm{t})$ it is below the current estimate of MSY from 103000 to $114000 \mathrm{t}$ catches. Estimated values of fishing mortality and SSB for 2008 are also close to MSY - related values, indicating a fully exploited stock. A total of 34565 Bigeye tuna were tagged and released, most of them being released off the coast of Tanzania. So far 5461 fish (15.8\%) have been recovered and reported, most of them by the European and Seychelles purse seine fleets. Moreover, in 2010 a bigeye was recovered in the ICCAT area, off the coast of Namibia (Herrera and Pierre 2010).

\section{Albacore tuna}

Albacore (T. alalunga) is a temperate tuna living mainly in the mid oceanic gyres of the Pacific, Indian and Atlantic Oceans. Indian Ocean albacore is distributed from $5^{\circ} \mathrm{N}$ to $40^{\circ} \mathrm{S}$. Albacore is a highly migratory species and individuals swim large distances during their life time. The maximum age reported for Indian Ocean albacore stock in the Indian Ocean is eight years. However, this may be an underestimate as albacore have been reported to live to at least 10 years in the Pacific Ocean (IOTC 2010). The catches increased markedly during the 1990's due to the use of drift gillnets, with total catches reaching around 30,000t. Total annual catches averaged 39,766 tover the period 2006 to 2010, and total catches peaked at 2008 (44410 $\mathrm{t}$ ) and the provisional 2010 catch stands at $42950 \mathrm{t}$; the lowest catch was observed 
in 2006 at $29873 \mathrm{t}$ and catches in 2009 were $38718 \mathrm{t}$, which is the lowest catch. The catches of albacore by longliners from the South Korea, recorded since 1965, have never been above $10000 \mathrm{t}$. Important albacore catches of around $3000 \mathrm{t}$ to $5,900 \mathrm{t}$ have been recorded in recent years for a fleet of fresh tuna longliners operating in Indonesia. Large sized $(131 \mathrm{~cm})$ albacore are also taken seasonally in certain areas, most often free swimming schools, by the purse seine fishery. However, the available stock status information indicates that the condition of the stock is not likely to change markedly over the next two to three years and if the price of albacore tuna remains low compared to other tuna species no immediate management action should be required on the part of the IOTC. The stock is in an overshed state as spawning biomass is below the $\mathrm{B}_{\mathrm{MSY}}$ level $\left(\mathrm{B}_{\text {current }} / \mathrm{B}_{\mathrm{MSY}}=\right.$ 0.89; Range: $0.65-1.12$ ). The median estimate of MSY is estimated to be 29900 tonnes (range: 21500 to $33100 \mathrm{t}$ ). It is concluded that the available evidence indicates considerable risk to the stock status at current effort levels.

\section{Kawakawa}

Kawakawa (Euthynnus affinis) live in open waters close to the shoreline and prefers water temperature ranging from 18 to $29^{\circ} \mathrm{C}$. Kawakawa form schools by size with other species sometimes containing over 5000 individuals. Kawakawa are often found with yellowfin, skipjack and frigate tunas. Kawakawa are typically found in surface waters, however, they may live in a range of depths of over $400 \mathrm{~m}$, possibly to feed. On the Natal coast in South Africa, sexual maturity is attained at $45-50 \mathrm{~cm}$ and spawning occurs mostly during summer. A $1.4 \mathrm{~kg}$ female ( $48 \mathrm{~cm} \mathrm{FL)} \mathrm{may} \mathrm{spawn} \mathrm{approximately}$ 0.21 million eggs per batch. Kawakawa is caught mainly by gillnets and purse seiners and may be an important bycatch of the industrial purse seiners. A high percentage of the kawakawa captured by Thai purse seiners in the Andaman Sea comprised of fish of 8 to $42 \mathrm{~cm}$ long. Annual estimates of catch of Kawakawa increased markedly from around $10,000 \mathrm{t}$ in the late 1970 's to reach the 50,000 $\mathrm{t}$ mark in the mid - 1980's. Since 1997, catches have been around $100000 \mathrm{t}$. The average annual catch estimated for the period 2006 to 2010 is $125639 \mathrm{t}$. In recent years, the countries attributed with the highest catches are India, Indonesia and Iran. No quantitative stock assessment is currently available for Kawakawa in the Indian Ocean, therefore the stock status is uncertain, and the scientific committee notes the catches have been relatively stable for the past 10 years (IOTC 2009).

\section{Bullet tuna}

Bullet tuna (Auxis rochei) is a neritic tuna species found in the equatorial areas of the major oceans. It is highly migratory species with a strong schooling behavior. Adults are principally caught in coastal waters and around islands that have oceanic salinities. Adults can grow to $50 \mathrm{~cm}$ fork length. The fisheries in the Indian Ocean mainly catch Bullet tuna ranging between 15 and $25 \mathrm{~cm}$. Bullet tuna mature at around two years old - about $35 \mathrm{~cm}$ (FL). It is a multiple spawner with fecundity ranging between 31000 and 103000 eggs per spawning (according to the size of the fish). Bullet tuna is caught mainly by gillnets and line across the broader Indian Ocean area and this species is also an important catch for artisanal purse seiners. Estimated catches of Bullet tuna were around 1,000 $t$ in the early 1990 's and peaked at $2498 \mathrm{t}$ in 2007 . The average annual catch estimated for the period 2005-2010 is $2361 \mathrm{t}$. In recent years, the countries attributed with the highest catches of Bullet tuna are India, Indonesia and Sri Lanka. There is only a little information available on the stock structure of Bullet tuna in the Indian Ocean; therefore the stock status is uncertain.

\section{Frigate tuna}

Frigate tuna (A. thazard) is a highly migratory species found in both coastal and oceanic waters. It is highly gregarious and often schools with other Scombrids. In other oceans, Frigate tuna grows to around $65 \mathrm{~cm}$ fork length but the largest size reported for the Indian Ocean is $58 \mathrm{~cm}$ (off Sri Lanka). Size at first maturity is between $29 \mathrm{~cm}$ and 35 $\mathrm{cm}$ fork length depending on location. In the southern Indian Ocean the spawning season extends from August to April whereas north of the equator it is from January to April. Fecundity ranges between 200000 and 1.6 million eggs per spawning (depending on size). Frigate tuna feeds on small fish, squids and planktonic crustaceans (decopods and stomatopods). Because of their high abundance, Frigate tuna are considered to be an important prey for a range of species, especially the commercial tunas.

Frigate tuna is taken from across the Indian Ocean area using gillnets, bait boats and lines. This species is also an important catch for industrial purse seiners. Estimated catches have increased steadily since the late 1970's, reaching around $12312 \mathrm{t}$ in the early 1985 's and over $30000 \mathrm{t}$ by the mid 1996. The average annual catch estimated for the period 2005 to 2010 is $24777 \mathrm{t}$. In recent years, the countries attributed 
with the highest catches are India, Indonesia, Maldives and Iran and Sri Lanka. The size of Frigate tunas taken by the Indian Ocean fisheries typically ranges between 25 and $40 \mathrm{~cm}$ depending on the type of gear used, season and location.

\section{Gear wise species composition}

Chiefly the drift gillnet with mesh size 60 to $160 \mathrm{~mm}$, hooks and lines, purse seine, long line and pole and line are employed for the exploitation of tuna along the Indian Ocean. The use of new fishing technologies such as FADs by purse seiners and super-cold storage by some longline vessels have increased the scope of exploitation and the rate and magnitude of declines (Lee et al. 2005; Okamoto et al. 2004). Purse seine is commonly an industrial scale fishery used to catch tuna destined for canneries, the tuna landings by purse seine stabilized around $241754 \mathrm{t}$ to $352309 \mathrm{t}$ during 1990-1995 respectively and then continually increased to $431312 \mathrm{t}$ in 2010. Longline is a less fuel intensive and more selective method of fishing, this method of fishing may be carried out on a large, industrial scale or on a small, artisanal scale. The long line introduced in the late 1960's reflects a decline in the catch from $90582 \mathrm{t}$ during 1966-1970 to $98541 \mathrm{t}$ during 1975, and further to an increase up to 2005 (248958 t), then declined to $198934 \mathrm{t}$ in 2009 . The landings by gillnet from time to time showed an increasing trend in the production (74446t) during 1980-1985 and catch increased greatly up to $376672 \mathrm{t}$ in 2010 . Tuna production by bait boat initially declined from $28165 \mathrm{t}$ in 1980 and then steadily increased to $148266 \mathrm{t}$ up to 2005 and then declined to $130630 \mathrm{t}$ in 2010 (Table 2). The average tuna production by different types of fishing fleet under the mechanized sector indicate that during 2006-2010, the purse seiners account for about $36 \%$ of the catch, gillnet $31 \%$, long line $15 \%$, bait boat $10 \%$, pole and line $7 \%$ and the remaining by a variety of other gears $1 \%$ in Fig. 6 .

The composition and extent of bycatch taken in fisheries targeting tuna varies by gear and by area. However non- reporting and under-reporting of bycatch are characteristic of all gear types and, consequently, it is difficult to provide accurate estimates of bycatch. Estimates of bycatch in tuna fisheries tend to be adhoc and relate to studies of specific fisheries, species or types of bycatch (e.g., seabirds) rather than provide a comprehensive picture of the nature and extent of bycatch. However, it is possible to draw some general conclusions from the literature about the nature of bycatch in longline fisheries for tuna (Kelleher 2005; Bromhead et al. 2003; Romanov 2002).

\section{Food and Feeding Habits of Indian Ocean Tuna}

Catches of tunas and billshes by longline and surface tuna sheries have dramatically increased during the last two decades in the Indian Ocean (FAO 2008), whereas our knowledge on the biological aspects and the predator-prey interactions in this ocean is still limited. Many workers have investigated the diet composition of large pelagic fishes such as tunas and related species, due to their commercial value. Most of these studies took place in the Pacific and Atlantic Oceans (Stillwell and Kohler, 1985; HernandezGarcia, 1995; Bertrand et al. 2002). Very few studies have investigated the diet of large pelagic fish predators in the Indian Ocean. Watanabe (1960) has analyzed the food composition of 35 bigeye tunas and 91 yellowfin tunas caught in the Eastern Indian Ocean during the 1956-1957 period. Other studies have analyzed the main prey groups eaten by yellowfin tuna and skipjack tuna in the Seychelles and in the Mozambique area (Roger 1994), and around India (Maldeniya 1996). A total of 4181 stomachs of yellowfin tuna (22-164 cm FL), mainly caught by gillnets in the period from July 1984 to June 1986 were analyzed by Maldeniya (1996) in Sri Lankan waters. The diet of yellowfin tuna around Sri Lanka comprised a variety of macro zooplanktonic and nektonic organisms. Potier et al. (2004) investigated the feeding partitioning among yellowfin and

Table 2. Tuna production (in tonnes) by different gears operated by the mechanized sector in Indian Ocean during 1950-2010

\begin{tabular}{cccccccccccccc}
\hline \hline Gears & 1950 & 1955 & 1960 & 1965 & 1970 & 1975 & 1980 & 1985 & 1990 & 1995 & 2000 & 2005 & 2010 \\
\hline Bait Boat & 11003 & 12426 & 13309 & 13211 & 25796 & 33935 & 28165 & 46428 & 74360 & 94802 & 119899 & 148266 & 130630 \\
Gillnet & 5210 & 7668 & 10884 & 19640 & 29864 & 36390 & 59897 & 74446 & 142107 & 175016 & 259296 & 316289 & 376672 \\
Pole and Line & 2080 & 2957 & 3735 & 5515 & 7629 & 9970 & 17923 & 25809 & 48394 & 71847 & 85320 & 100674 & 99417 \\
Longline & 0 & 28055 & 88568 & 107629 & 136175 & 90582 & 98541 & 102734 & 136701 & 226315 & 253895 & 248958 & 198934 \\
Other gear & 1081 & 1749 & 3564 & 7378 & 6970 & 11747 & 16795 & 11843 & 11436 & 12460 & 12677 & 13470 & 12836 \\
Purse seine & 233 & 1504 & 1885 & 2899 & 3517 & 5602 & 16663 & 87123 & 241754 & 352309 & 403635 & 490988 & 431312 \\
\hline
\end{tabular}

Source: IOTC 2010 
bigeye tunas in the Western Indian Ocean using preliminary data from longline and purse seine caught sh. In the present study we created a detail database on prey position of the diets of tuna and tuna like species in the Indian Ocean. Copepod nauplii, calanoids, cyclopoids and cladocerans (all Crustacea) were the main prey of the larvae of southern bluefin Thunnus maccoyii and albacore tuna T. alalunga in the eastern Indian Ocean, although the importance of each prey type differed between the two species (Young and Davis 1990). Stomach contents of yellowfin and skipjack tuna caught by trolling and purse seining in the tropical western Indian Ocean, together with those of the prey-fish found in their stomachs, have been analyzed (Roger 1994). These tunas are thus considered day time-feeders. Purseseine-caught tunas, which belong to large schools, have a much higher number of prey-fish in their stomachs than tunas caught by trolling on small schools. Similarly, preyfish from purse-seine tunas have a much higher number of planktonic prey in their stomachs than those from trollcaught tunas. Therefore, these tunas adopt a wandering strategy in small schools when food resources are scarce and form large schools when they are abundant (Roger 1994). Poiter et al. (2007) studied food and feeding habits of yellowfin tuna in the Western equatorial Indian Ocean. Fortytwo families and 4791 prey items were counted in the stomachs of the 111 yellown tunas sampled. On average $43.2 \%$ prey were found per stomach, among these Crustaceans contributed (71\%), Crab larvae (megalopa stage) dominated in the yellowfin diet $25 \%$ and followed by Charybdis smithi (7.7\%).

In Sri Lankan waters Dissanayake et al. 2008 studied the food and feeding habits of yellowfin tuna, on average 33 prey items were found per stomach and dominant prey items were crustaceans, especially swimming crab, C. smithi followed by fishes belonging to family Sphyraenidae and Engraulididae. (Rohit and Rammohan 2009) It was reported of the 110 stomachs analyzed for food and feeding studies, $14.7 \%$ were found to be empty, $33.3 \%$, one-fourth full, $24.5 \%$ half full, $6.9 \%$ three-fourth full and $20.6 \%$ full. Gut contents mainly consisted of crustaceans (42.5\%), fishes (34.7\%), and cephalopods (15.5\%). Fully digested matter comprised $7.3 \%$ of the food analyzed. Many of the stomachs, though found empty, had squid beaks in the stomach.

Only limited studies were undertaken on quantitative investigations of the feeding ecology of the longtail tuna. The feeding ecology of longtail tuna was studied in northern and eastern Australia (Griffiths et al. 2007), and reported that the longtail tuna as an opportunistic predator feeding on small pelagic fishes, cephalopods and crustaceans and also indicated variation in diversity and composition of the diet over space and time and with size of the fish. Examination of guts indicated that the species is non-selective in feeding habit and feeds on teleost fishes (82\%), crustaceans (4.6\%) and molluscs (13.4\%). Sardines (Sardinella sp.), anchovies (Thryssa sp.), scads (Decapterus sp. and Selar sp.), ribbonfishes (Trichiurus sp.), flying fish, hemiramphids, small tuna ( $A$. rochei), threadfin breams and small perches (Lethrinus sp.) dominate the fish components of their gut (Abdussamad et al. 2012).

The food and feeding habits of $S$. orientalis based on the data covering the period 2006-10 was observed in Indian waters (Sivadas et al. 2012). Even though stomachs in different states of fullness were observed, $60 \%$ of the stomachs were empty. Qualitative analysis showed that the food comprised mainly of fishes, crustaceans (crabs and prawns) and cephalopods (squids). Out of the stomachs with food, $75 \%$ were with fish, $20 \%$ with crustaceans and the rest with cephalopods. Among fishes, Selar sp., Decapterus sp., Auxis sp., Sardinella sp., Stolephorus sp., and Platycephalus sp. were noticed (Sivadas et al. 2012).

An annual variation in feeding with high feeding intensity in alternate years was observed for $A$. thazard (Ghosh et al. 2012). Fishes possessing empty stomachs were encountered frequently in all the months for all the years. The average contribution of fishes with empty stomach was $74 \%$. The food items in the diet of $A$. thazard were classified broadly into three major groups: crustaceans, cephalopods and finfishes. Crustaceans comprised mainly non-penaeid prawn, Acetes spp. and crabs. The squid, Loligo duvaucelli dominated among cephalopods. Sardines, anchovies, mackerels, scads and tuna juveniles were dominant among finfishes. The feeding intensity was more in the months of March, April, June and December.

The diet, food consumption, and ration of mackerel tuna (E. affinis) were studied in Australian neritic waters (Griffiths et al. 2009). Overall, 43 prey taxa were identified from 271 stomachs. The diet was primarily pelagic clupeoids $(78 \%$ by wetweight; $71 \%$ by frequency of occurrence (FO) and demersal fish (19\% WW; $32 \%$ FO). Small tuna seemed to target small pelagic crustaceans and teleosts, and medium and large tuna to consume larger pelagic and demersal teleosts. Prey consumption increased with tuna size from 26.42 to 
$108.03 \mathrm{~g} \mathrm{~d}^{-1}$ for small and large tuna, respectively. Diet studies are becoming increasingly important in informing ecosystem models, and this study confirmed the need for sampling regimes to capture temporal and size-related variation in diet composition, to maximize the utility of data for use in such models (Griffiths et al. 2009).

\section{Length - Weight Relationship of Tuna}

Table 3 shows Length - Weight Relationship of tuna caught from the Indian Ocean. In the oceanic fishery results of length - weight relationship of yellowfin tuna available with respect to the stock occurring in different sectors of the Indian Ocean (Morita 1973; Pillai et al. 1993; John 1995; Dissanayake et al. 2008; Ghosh et al. 2012). A comparison of the length-weight relationship observed in different studies is presented below. The size of exploited yellowfin tuna in the Indian Ocean ranged from $30 \mathrm{~cm}$ to $180 \mathrm{~cm}$ fork length, Maximum length: $240 \mathrm{~cm}$ FL and Maximum weight was observed $200 \mathrm{~kg}$ (IOTC 2011). Newly recruited fish are primarily caught by the purse seine fishery on floating objects. Males are predominant in the catches of larger fish at sizes more than $140 \mathrm{~cm}$ (this is also the case in other oceans). The size of exploited bigeye tuna in the Indian Ocean ranged from $30 \mathrm{~cm}$ to $180 \mathrm{~cm}$ fork length. Newly recruited bigeye tuna are primarily caught by the purse seine fishery on floating objects. Smaller fish (juveniles) form mixed schools with skipjack tuna and juvenile yellowfin tuna and are mainly limited to surface tropical waters, while larger fish are found in sub-surface waters (IOTC 2011). Anrose and Kar (2010) studied some aspects of the biology of bigeye tuna in Andaman waters, Indian Ocean. He observed that the males were in the FL range of $104-173 \mathrm{~cm}$ while the females were in the FL range of $122-172 \mathrm{~cm}$. The length weight relationships calculated are Male: $\mathrm{W}=0.00001 \mathrm{~L}^{3.25}$ $(\mathrm{r}=0.96)$ Female: $\mathrm{W}=0.00001 \mathrm{~L}^{3.01}(\mathrm{r}=0.98)$; Pooled: $\mathrm{W}=$ $0.00001 \mathrm{~L}^{3.09}(\mathrm{r}=0.96)$. The length and weight relationship of albacore tuna from the Indian Ocean was studied by Hsu (1999) and was determined using data from gillnet catches. Altogether 2499 specimens were measured, range of FL $46.2-112 \mathrm{~cm}$ and length weight relationship $\mathrm{W}=0.056907$ $\mathrm{FL}^{2.7514}$. The length frequency distribution of yellowfin tuna ranged from $30-150 \mathrm{~cm}$ in the north western and north eastern coastal waters of Sri Lanka. The length classes of 102.5-117.5 cm were observed peaks from January to April and those of $92.5 \mathrm{~cm}$ and $97.5 \mathrm{~cm}$ peaks from October to December (Dissanayake et al. 2008). The length and weight relationship was calculated for bullet tuna with $\mathrm{W}$ equal to $0.0542 \mathrm{~L}^{2.68}$ in Turkish waters (Kahraman et al. 2011).

\section{Growth and mortality parameters}

The reproductive characteristics of a stock along with those of growth and mortality are among the most important factors in determining the regenerative ability of a population

Table 3. Length and Weight Relationship of tuna caught from Indian Ocean

\begin{tabular}{|c|c|c|c|c|c|}
\hline$\overline{\text { Area }}$ & Species & Gear & Size range $(\mathrm{cm})$ & Length-weight relationship & Source \\
\hline Eastern Indian Ocean & Yellowfin & Long line & $84-174$ & $\mathrm{Wx}=0.000018 \mathrm{~L}^{2.9841}$ & Morita 1973 \\
\hline Western Indian Ocean & Yellowfin & Purse Seine & 64 & $\mathrm{~W}=0.00001585 \mathrm{~L}^{3.0449}$ & Stequert et al. 1996 \\
\hline Indian EEZ & Yellowfin & Long line & $59-155$ & $\mathrm{~W}=0.000039528 \mathrm{~L}^{2.8318}$ & John and Sudarsan 1993 \\
\hline Bay of Bengal & Yellowfin & Hook and line & $25-190$ & $\mathrm{~W}=0.008634 \mathrm{~L}$ & Rohit and Rammohan 2009 \\
\hline Srilankan Waters & Yellowfin & Long line & $30-150$ & & Dissanayake et al. 2008 \\
\hline Maldives & Yellowfin & & $25-145$ & $\mathrm{~W}=0.00002863 \mathrm{FL}^{2.897}$ & Adam and Anderson 1996 \\
\hline Andaman Waters & Bigeye & & $122-172$ & $\mathrm{~W}=0.00001 \mathrm{~L}^{3.09}$ & Anrose and Kar 2010 \\
\hline Australia & Southern bluefin & Long line & $142-209$ & & Davis and Fairly 2001 \\
\hline Indian Ocean & Albacore & Gillnet & $46.2 \pm 112.0$ & $\mathrm{~W}=0.056907 \mathrm{FL}^{2.7514}$ & Hsu 1999 \\
\hline Indian waters & Skipjack & Gillnet & $12-082$ & $\mathrm{~W}=0.0109 \mathrm{~L}^{3.147}$ & Koya et al. 2012 \\
\hline Indian waters & Long tail & & $23-111$ & $\mathrm{~W}=-0.0148 \mathrm{~L}^{3.0}$ & Abdussamad et al. 2012 \\
\hline Indian waters & Long tail & & $62.75-73.27$ & $\mathrm{~W}=-1.031743+2.514743 \log \mathrm{L}$ & Ghosh et al. 2010 \\
\hline Indian waters & Kawa kawa & & $31.21-43.88$ & $\mathrm{~W}=-1.931304+3.0558233 \log \mathrm{L}$ & Ghosh et al. 2010 \\
\hline Indian waters & Frigate tuna & & $38.7-47.97$ & $\mathrm{~W}=-2.082723+3.171805 \log \mathrm{L}$ & Ghosh et al. 2010 \\
\hline Indian waters & Frigate tuna & & $18-55.9$ & $\mathrm{~W}=-2.082723+3.171805 \log \mathrm{L}$ & Ghosh et al. 2012 \\
\hline Indian waters & Striped bonito & & $16-68$ & $\mathrm{~W}=0.00869 \mathrm{~L}^{3.1}$ & Sivadas et al. 2012 \\
\hline Indian waters & Dogtooth tuna & & $32.5-162$ & $\mathrm{~W}=0.0105 \mathrm{~L}^{3.065}$ & Joshi et al. 2012 \\
\hline
\end{tabular}


Table 4. Growth Parameters and population characteristics of tuna species

\begin{tabular}{|c|c|c|c|c|c|c|c|c|c|c|c|}
\hline$\overline{\overline{\text { Countries }}}$ & Species & $\overline{\mathrm{L}}$ & $\overline{\mathrm{K}}$ & $\overline{\mathrm{M}}$ & $\overline{Z Z}$ & 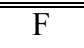 & $\overline{\mathrm{U}}$ & $\overline{\mathrm{E}}$ & $\overline{\varnothing \varnothing}$ & $\mathrm{t}_{\mathrm{o}}$ & Sources \\
\hline East coast of India & Yellowfin & 197.42 & 0.3 & 0.4 & 0.71 & 0.23 & 0.162 & 0.32 & 4 & 0.1157 & Rohit et al. 2012 \\
\hline Indian waters & Skipjack & 92 & 0.5 & 0.57 & 1.41 & 0.853 & & 0.605 & & -0.0012 & Koya et al. 2012 \\
\hline West coast of India & Kawa kawa & 72.5 & 0.56 & 0.94 & 1.69 & 0.75 & 0.36 & 0.44 & 3.469 & -0.0327 & Ghosh et al. 2010 \\
\hline Indian waters & Frigate tuna & 57.95 & 1.2 & 1.65 & 4.89 & 3.24 & & 0.66 & 3.605 & -0.0075 & Ghosh et al. 2012 \\
\hline West coast of India & Bullet tuna & 40 & 1 & 1.67 & 6.78 & 5.11 & 0.7 & & & -0.014 & Pillai and Ganga 2005 \\
\hline West coast of India & Long tail tuna & 107.4 & 0.18 & 0.4 & 1.12 & 0.72 & 0.43 & 0.64 & 3.317 & -0.073 & Ghosh et al. 2010 \\
\hline Indian waters & Long tail tuna & 123.5 & 0.51 & 0.77 & 3.72 & 2.94 & & 0.799 & & -0.032 & Abdussamad et al. 2012 \\
\hline Indian waters & Oriental bonito & 74.75 & 0.68 & 1.09 & 3.18 & 2.09 & & 0.66 & 3.58 & & Sivadas et al. 2012 \\
\hline Indian waters & Dogtooth tuna & 163.6 & 0.43 & 0.527 & 1.06 & 0.49 & 0.302 & & & -0.12 & Joshi et al. 2012 \\
\hline Indian Ocean & Bigeye tuna & 169 & 0.0009 & & 0.8 & & & & & -123 & Stequert and Conand 2004 \\
\hline Maldives & Skipjack & 78 & 0.625 & & & & & & & & Hafiz 1985 \\
\hline Maldives & Skipjack & 82 & 0.45 & & & & & & & & Hafiz 1986 \\
\hline Sri Lankan water & Kawa kawa & 76.8 & 0.52 & 0.9 & 1.07 & 0.17 & & 0.24 & & & Dayaratne and De Silva 1991 \\
\hline Taiwan & Albacore & 171.4 & 0.118 & 0.24 & 0.57 & 0.33 & & & & & Chang et al. 1993 \\
\hline
\end{tabular}

(Quinn and Dersio 1999). Numerous studies have been conducted on the age and growth of tunas in the Indian Ocean. Table 4 shows estimated growth parameters of tuna species. The fork length of $T$. albacares during the study period ranged from 30-190 cm with mode at $130 \mathrm{~cm}$ (Rohit and Rammohan 2009). Growth parameters, $\mathrm{L}_{\infty}$ and $\mathrm{K}$ of $T$. albacares were estimated to be $149.6 \mathrm{~cm}$ and $0.75 /$ year. The natural mortality rate $\mathrm{M}$ was estimated to be $0.96 /$ year, the total mortality rate $\mathrm{Z} 4.7 /$ year, the average fishing mortality F 1.41/year and the exploitation rate U 0.539 was observed in Chennai coast by Kasim and Mohan (2009).

Marcille and Stequert, (1976) analyzed length frequency data of skipjack caught from the Indian Ocean, He noticed that $\mathrm{L}_{\infty}=60.6 \mathrm{~cm}$ and $\mathrm{K}=0.93 /$ year. Sivasubramanium (1985) reported $\mathrm{L}_{\infty}=77 \mathrm{~cm}$ and $\mathrm{K}=0.52 /$ year in Sri Lankan waters. Koya et al. (2012) studied the fishery and population dynamics of skipjack tuna, during the period 2006-2010 in Indian waters. Koya et al. (2012), studied the population dynamics of skipjack tuna, and observed the length-weight relationship was $\mathrm{W}=0.0109 \mathrm{~L}^{3.147}$. The von Bertalanffy growth factors (VBGF) were $\mathrm{L}_{\infty}=92.0 \mathrm{~cm}, \mathrm{~K}=0.50 \mathrm{yr}-1$ and to $=-0.0012$. Estimate of total mortality $(\mathrm{Z})$ was 1.41 / year, natural mortality $(\mathrm{M}) 0.557 /$ year, fishing mortality $(\mathrm{F})$ $0.853 /$ year and exploitation rate (E) 0.605 .

Chang et al. 1993 studied age and growth parameters of Indian Ocean albacore tuna from Taiwan waters, and $\mathrm{L}_{\infty}$ and $\mathrm{K}$ deemed to be $171.4 \mathrm{~cm}$ and $0.118 /$ year, respectively. The natural morality rate $\mathrm{M}$ was estimated to be 0.24 , total mortality Z ( $0.57 /$ year), fishing mortality F ( $0.33 /$ year). The age and growth of bigeye tuna (T. obesus) from the Western
Indian Ocean were investigated using otoliths and first dorsal spines by Stéquert and Conand (2004). The von Bertalanffy growth curve is $\mathrm{FL}=168.99\left(1-\mathrm{e}-0.000879^{(\mathrm{t}+123.38)}\right)$, where $\mathrm{FL}$ in $\mathrm{cm}$ and $\mathrm{t}$ in days were used. The results obtained with spines and otoliths are comparable until 3 years old, but spines are not suitable for larger fish (Stéquert and Conand 2004). Farley et al. (2006) provided information on the age and growth of bigeye tuna in the eastern and western Australian Fishing Zone based on otoliths. Preliminary results suggest that growth rates vary between areas, and bigeye in the western Pacific Ocean grew faster than bigeye in the eastern Indian Ocean.

The fishery, population characteristics and stock estimates of frigate tuna from Indian waters were studied during 2006-2010 by Ghosh et al. (2012). Length at first maturity was estimated as $29.7 \mathrm{~cm}$ and fecundity was observed as $807986 \mathrm{~kg} /$ body weight. The von Bertalanffy growth equation derived was; $\mathrm{Lt}=57.95\left[1-\mathrm{e}^{-1.2(\mathrm{t}+0.0075)}\right]$. The growth parameters, $\mathrm{L}_{\infty}$ and $\mathrm{K}$, were estimated at $57.95 \mathrm{~cm}$ and $1.2 /$ year. Growth performance index was $3.605, \mathrm{t}_{0}-0.0075$ and the length at first capture was $32.83 \mathrm{~cm}$. The natural mortality, fishing mortality and total mortality were 1.65, 3.24 and 4.89/year respectively and with an exploitation ratio $0.66 . \mathrm{E}_{\max }$ estimated was 0.778 , which is higher than the present exploitation, indicating scope for further exploitation.

James et al. (1992) studied population characteristics and stock status of bullet tuna in Indian waters. The growth parameters, $\mathrm{L}_{\infty}$ and $\mathrm{K}$, were estimated at $37.00 \mathrm{~cm}$ and 0.638 / year. The natural morality rate $M$ was estimated 1.024 year, total mortality Z (2.739/year), fishing mortality F (1.7147/ 
year), exploitation rate $U(0.74)$ from the Indian Seas. Estimates of exploitation rate of bullet tuna indicate that they are exploited below the optimum level (IOTC 2011). Above findings suggests that there is considerable scope for improving their production.

Fishery, biology and population characteristics of the longtail tuna were studied during 2006-10 by Abdussamad et al. (2012). Growth parameters of the species were: $L_{\infty}=123.5$ $\mathrm{cm}(\mathrm{FL}), \mathrm{K}=0.51 /$ year and $\mathrm{t}_{\mathrm{o}}=-0.0319$ years. Natural mortality (M) was $0.77 /$ year, total mortality (Z) 3.72/year and fishing mortality (F) 2.94/year. Spawning stock biomass formed $65.4 \%$ of the standing stock. Fishery, biology and population characteristics of the Oriental bonito Sarda orientalis were studied during 2006-10 by Sivadas et al.( 2012). The von Bertalanffy growth equation was: $\mathrm{Lt}=74.75\left[1 \mathrm{1}^{\mathrm{e}-0.68(t+0)}\right]$. Accordingly, the species attained a size of $40 \mathrm{~cm}$ by the end of $1^{\text {st }}$ year and $50 \mathrm{~cm}$ by the end of $2^{\text {nd }}$ year. Growth parameters of the species were: $\mathrm{L}_{\infty}=74.5 \mathrm{~cm}(\mathrm{FL}), \mathrm{K}=0.68 /$ year and growth performance index (Ø) was 3.58. Natural mortality (M) was 1.09/year, total mortality (Z) 3.18/year, fishing mortality (F) 2.09/year and exploitation ratio (E) was 0.60 . The Fishery and population dynamics of dogtooth tuna exploited along the Indian coast was studied by Joshi et al. (2012). The estimated VBGF parameters of the species are $\mathrm{L}_{\infty}=163 \mathrm{~cm}, \mathrm{~K}=0.43 \mathrm{yr}^{-1}, \mathrm{t}_{0}=-0.12$ and other important population values and ratios like $\mathrm{L}_{\text {opp }}, \mathrm{Lm} / \mathrm{L}_{\infty}$ and Lopt $/ \mathrm{L}_{\infty}$ were estimated at $75.8 \mathrm{~cm}, 0.04217$, and 0.463 respectively. Natural mortality (M) was $0.527 /$ year, total mortality $(Z)$ 1.06/year and fishing mortality (F) $0.49 /$ year and exploitation ratio (U) 0.3021 respectively, the value of $\mathrm{M} / \mathrm{K}$ ratio was obtained 1.333 .

Fishery and population characteristics of the bullet tuna (A. rochei) along the South Kerala Coast were reported by Gopakumar and Ajithkumar (1993). Kahraman et al. (2011) and age and growth parameters of bullet tuna were identified $(A$. rochei) in Turkish waters. The growth parameters based on standard von bertalanffy growth function are the following: for males, $\mathrm{L}_{\infty}$ (asymptotic length) is equal to $60.417 \mathrm{~cm} ; \mathrm{K}$ (growth coefficient) is equal to $0.159 ; \mathrm{t}_{0}$ (age at zero length) is equal to 4.311 ; for females, $\mathrm{L}_{\infty}$ is equal to $49.238 \mathrm{~cm}$; $\mathrm{K}$ is equal to $0.312 ; \mathrm{t}_{0}$ is equal to 3.011 ; for both sexes, $\mathrm{L}_{\infty}$ is equal to $57.388 \mathrm{~cm}$; $\mathrm{K}$ is equal to 0.181 and $\mathrm{t}_{0}$ is equal to 4.155 , respectively.

\section{Reproductive Biology of Tunas}

Knowledge on the reproductive strategy of tuna and tuna like species is important for a comprehensive understanding of the population dynamics and for predicting the effect of fishing on the reproductive potential of a stock, which is essential for taking effective management decisions and for the sustainability of the resource. (Scheafer 2001; Murua and Motos 2006). Tunas are predominately dioecious, and there appears to be no sexual dimorphism in external morphological characters. Tunas are oviparous, have asynchronous oocyte development, and are considered to be multiple or batch spawners, shedding their gametes directly into the sea, where egg fertilization occurs (de Vlaming 1983). In recent years accurate interpretation and classification of reproductive conditions and estimates of spawning potential for tunas have largely been the result of utilizing histological techniques and appropriate classification criteria (Schaefer 1998). For this propose, the use of accurate techniques is necessary to avoid biases as the estimation of these parameters (sex ratio, size at first maturity, spawning season, annual fecundity, etc.) improves the ability to manage the stock (Nootmorn et al. 2005).

\section{Gonad development and maturation}

Table 5 shows length at $50 \%$ maturity and fecundity of tuna species caught from India Ocean. Besides the description of different oocytes developmental stages, some preliminary results that could be compared with previous studies have been obtained. Zudaire et al. (2010) studied the reproductive

Table 5. Length at 50\% maturity and fecundity of tuna species caught from India Ocean

\begin{tabular}{cccccc}
\hline \hline Species & No. of Fish & Fish length & Length at $50 \%$ Maturity & $\begin{array}{c}\text { Estimated fecundity eggs } \\
\text { per kg body weight }\end{array}$ & Source \\
\hline Skipjack & 1269 & $32-68$ & $41-43 \mathrm{~cm}$ & $100828-627,325$ & Grande et al. 2010 \\
Yellowfin & 423 & $45-165$ & 77.8 & 2.5 million & Zudaire et al. 2010 \\
Frigate & 884 & $38.7-47.97$ & 29.7 & 807986 & Ghosh et al. 2012 \\
Striped bonito & 144 & $39-52$ & 42 & 404048 & Sivadas et al. 2012 \\
Longtail & & $21-111$ & 51 & 132840 & Abdussamad et al. 2012 \\
Dogtooth & & $32.5-162$ & 69 & 315244 & Joshi et al. 2012 \\
\hline
\end{tabular}


biology of the yellowfin of the western Indian Ocean. The sex ratio of yellowfin was 1:0.9 (F:M), and varied from 1:0.2 to $1: 3$. Nevertheless, the proportion of males was significantly dominant among large size fishes $(>135 \mathrm{~cm})$ where the female proportion disappeared over $155 \mathrm{~cm}$ fork length. This pattern has been described for yellowfin in different oceans (Fonteneau 2002) and similar percentages were obtained for other tuna species (Sun et al. 2005; Marsac et al. 2006). Size at first maturity was estimated at $77.8 \mathrm{~cm}$, mean batch fecundity of 2.5 million oocytes and the mean relative batch fecundity of 61.9 oocytes per gram of body weight was calculated by Zudaire et al. (2010). Farley et al. (2003) reported the sex ratio of bigeye from longliner that found the proportion of males to be more than females (1.24:1) in the Coral Sea, while the sex ratio in other areas in western Australia, southern Indonesia waters revealed the proportion to be about 1:1. Maturity stage of female and male bigeye tuna was classified 1-5 stage and 2-5 stage, respectively. Mean GSI of female varied from 1.37 to 4.28 and males ranged from 0.60 to 2.089 (Nootmorn 2004). Kume (1962) reported size at first maturity as $92 \mathrm{~cm}$ in the Indian Ocean. Solovieff (1970) reported the spawning season of bigeye tuna in Indian Ocean to be pronounced during January to March.

Spawning Season of female and male yellowfin occurred between November and April in the eastern Indian Ocean (Nootmorn et al. 2005). Average monthly sex ratio was 1:0.4 and it was observed that sex ratio was equal 1:1 during spawning season. The size at first maturity of female and male was reported to be $109.69 \mathrm{~cm}(25 \mathrm{~kg})$ and $104.95 \mathrm{~cm}$ (22 kg) respectively. Said Koya et al. (2012) conducted studies during the period 2006-2010 on the fishery and population dynamics of skipjack tuna. Exploited size of the species ranged from 12 to $88 \mathrm{~cm}$ fork length (FL). Size at first maturity of the species was estimated at $44-45 \mathrm{~cm}$. Skipjack tuna are a very fast growing species, maturing at 2 to 3 years old ( $40 \mathrm{~cm}$ in length); maturity at ( $50 \%$ ) age $1-2$ years with size $41-43 \mathrm{~cm}$ FL in the Indian Ocean (IOTC 2010). The species mature and spawn round the whole year with the peak during December-March. Fecundity was estimated at 300718 per kg body weight. Recruitment to fishery takes place during most part of the year with the peak during May-November (Said Koya et al. 2012).

Albacore mature when they reach about $90 \mathrm{~cm}$ length and 4-5 years old. Spawning normally occurs between January and July (IOTC 2010). Sivadas et al. (2012) studied fishery and stock of striped bonito from the Indian coast. Immature and maturing fishes were observed in all months except from May to July. Mature fishes occurred in most of the months and were dominant in June and July. Spent fishes were also observed in almost all the months. The size at maturity was $42 \mathrm{~cm}$. Kahraman et al. (2010) observed some reproductive properties of bullet tuna (A. rochei) in Turkish waters. The sex ratio was 1:1.04, the most intensive spawning period was observed between June and August.

\section{Spawning behaviour}

Spawning patterns within tripe are diverse and complex. There are three types of spawning patterns exhibited by tunas: (1) confluent throughout tropical and subtropical regions (skipjack, yellowfin and bigeye), (2) regionally confined and protracted (frigate, bullet, longtail and bluefin tunas). Common to all these species with in tribe is the relationship between spawning activity and sea surface temperatures in excess of about $24^{\circ} \mathrm{C}$, because of their mode of reproduction, repetitive broadcast spaweners, and tunas must have very high lifetime fecundities to be successful (Schaefer 2001).

Yellowfin tuna is an important component of tuna fisheries worldwide and the major target species for tuna fishery in the Indian Ocean. Moreover, the area between $0^{\circ}$ north and $10^{\circ}$ south has been identified as the most active spawning ground and January, February and June have been the spawning months (Zudaire et al. 2010) when the most developed ovaries were found corresponding to the highest GSI values (over 1.5 GSI value). In the Indian Ocean, the spawning seems to occur mainly in the equatorial area (0$10^{\circ} \mathrm{S}$ ) from December to March, with the main spawning grounds west of $75^{\circ} \mathrm{E}$ (IOTC 2003). There are works that extend this period to between January to June (Zhu et al. 2008) and Stequert (2001) described two reproductive seasons related to the north monsoon (main spawning period) and south monsoon (less reproductive activity). Secondary spawning grounds exist off Sri Lanka and the Mozambique Channel and in the eastern Indian Ocean off Australia. Developmental stages of oocyte maturation and degenerative stages of postovulatory follicles in yellowfin tuna from the eastern Australian Fishing Zone of the Coral Sea are described by McPherson (1991). The time of spawning of yellowfin appeared to be during the late evening and early morning. Final oocyte maturation occurred in less than $24 \mathrm{~h}$; postovulatory follicles could not be identified in ovaries after $24 \mathrm{~h}$. The 
spawning stock of yellowfin in the north-western and centralwestern Coral Sea could be the major source of recruits for the tuna fisheries off the eastern coast of Australia (McPherson 1991). Previous studies have shown that yellowfin tuna caught by purse seine and handline have higher gonadosomatic indices than yellowfin caught by longline (Koido and Suzuki 1989).

Most of the skipjack tuna taken by fisheries in the Indian Ocean have already reproduced (IOTC 2011) because of their high fecundity and they spawn opportunistically throughout the year in the whole inter-equatorial Indian Ocean (north of $20^{\circ} \mathrm{S}$, with surface temperature greater than $24^{\circ} \mathrm{C}$ ) when conditions are favorable; typically they inhabit waters with temperatures of $15-30^{\circ} \mathrm{C}$ (IOTC 2010). The range of the bigeye tuna stock (as indicated by the distribution of catches) includes tropical areas, where reproduction occurs, and temperate waters which are believed to be feeding grounds. Spawning season extended from December to January and also in June in the eastern Indian Ocean (IOTC 2011). Nootmorn (2004) provided information on the reproductive biology of bigeye tuna in the eastern Indian Ocean. Samples were collected from longliners at Phuket, Thailand from January 2000 to August 2003, and suggested spawning activity from December to January and June in Indian Ocean (Solovieff 1970). The size at 50\% maturity for females and males was estimated at 88.08 and $86.85 \mathrm{~cm}$ FL respectively. Sex ratios varied between monthly samples and by length class, which indicated small-size bigeye tuna $(85-115 \mathrm{~cm} \mathrm{FL})$ comprised more females, while large bigeye tuna (125.00$155.00 \mathrm{~cm}$ FL) comprised more males (Nootmorn 2004). Little is known about the reproductive biology of albacore in the Indian Ocean but it appears, based on biological studies and on fishery data, that the main spawning grounds are located east of Madagascar between $15^{\circ}$ and $25^{\circ} \mathrm{S}$ during the 4 th and 1st quarters of each year. Like other tunas, adult albacore spawn in warm waters $\left(\mathrm{SST}>25^{\circ} \mathrm{C}\right)$.

Spawning habits of southern bluefin tuna (SBT) were better represented in the shallow catches than in deep water catches in their spawning ground in the Indian Ocean south of Bali (Davis and Farely 2001). There is a systematic change in depth distribution with size over the whole size range of southern bluefin tuna caught in the spawning ground. Conversely, non spawning fish were better represented in the deep catches than shallow catches. Surface water temperatures in the spawning ground usually exceed $24^{\circ} \mathrm{C}$ (Yukinawa and Miyabe 1984; Yukinawa 1987). These warm surface waters may be necessary for the survival of their eggs and larvae, but adult SBT normally feed in colder water (often as low as $5{ }^{\circ} \mathrm{C}$ [Olson 1980]). Temperatures of $10^{\circ}-15^{\circ} \mathrm{C}$ preferred by bigeye tuna (Mohri et al. 1997) may offer more favorable conditions for non spawning SBT and explain their string association with high bigeye index indices in the spawning ground.

\section{Spawning frequency and fecundity}

Spawning of yellowfin commenced in the north-western Coral Sea by October and had ceased in the central-western Coral Sea by late February. The average spawning frequency of female yellowfin in the western Coral Sea was once every 1.54 days. Significant differences in spawning frequency were found between different size classes of yellowfin; larger fish spawned more frequently. The determination of spawning frequency should also take into account longline fishing strategies because it is likely that spawning frequency affected by fish size and samples will determine whether they will be caught within or outside the spawning ground (Davis and Farley 2001). Yellowfin are multiple spawners and spawn every few days over the spawning period (Suzuki 1994). They spawn 6-7 batches of eggs during the spawning period in the western Indian Ocean. Sexual activity occurs during the months of November to February, while inactivity lasted from June to September. The estimated counts of hydrated oocytes of yellowfin in the eastern Indian Ocean varied from 0.3 to 5.3 million oocytes, while the average diameter of oocytes was found to be $0.56 \mathrm{~mm}$ (Nootmorn et al. 2005). The average relative fecundity was 404048 eggs per kg body weight in striped bonito (S. orientalis) in Indian waters observed by Sivadas et al. (2012). Relative fecundity varied from 293793 to 696512 for fishes between 39 and $52 \mathrm{~cm}$ FL. Fecundity of dominant species caught from the Indian Ocean water is given in Table 5.

\section{Biological reference points}

The biological reference point (BRP) often reflects the combination of several components of stock dynamics (recruitment, growth and mortality, usually including fishing mortality) into a single index. The index is usually expressed as an associated fishing mortality rate or a biomass level. Fisheries scientists have developed a series of BRP that may be used as thresholds or targets for management (Mace 1994). These thresholds or targets may be expressed as fishing mortality rates (F) or biomass levels (B). BRP are 
based on three kinds of analyses: Yield per Recruit (YPR), Stock-Recruitment (S-R), and Spawning Stock Biomass per Recruit (SPR). $\mathrm{F}_{0.1}$ and $\mathrm{F}_{\mathrm{MAX}}$ are often used as targets in fisheries management, although for some stocks $\mathrm{F}_{\mathrm{MAX}}$ might better be used as a threshold (not to be exceeded) (Mace 1994).

The estimate of bigeye tuna MSY ranges from 103000 to 114000 tonnes, the ratio of $\mathrm{F}_{\text {current }} / \mathrm{F}_{\mathrm{MSY}}$ is estimated to be less than 1.0 ( 0.67 to 0.79 , depending on the assessment), indicating that overshing is not occurring. The ratio of spawning biomass $\mathrm{B}_{\text {current }} / \mathrm{B}_{\mathrm{MSY}}$ is greater than or close to 1.0 (1.0 to 1.2 , depending on the assessment), indicating that the stock is not in an overshed state (ISSF 2012).

The median estimate of yellowfin MSY is estimated to be 357,000 tonnes (range: 290000 to $435000 \mathrm{t}$ ). The ratio of $\mathrm{F}_{\text {current }} / \mathrm{F}_{\mathrm{MSY}}$ is estimated at 0.84 (range: $0.63-1.1$ ), indicating that overshing is not occurring. The Scientific committee (SC) noted that the model results do not explain the high catches of yellown tuna from 2003 to 2006. Recent reductions in catches have lowered shing mortality in the stock. The stock is not in an overshed state as spawning biomass is above the $\mathrm{B}_{\mathrm{MSY}}$ level $\left(\mathrm{B}_{\text {current }} / \mathrm{B}_{\mathrm{MSY}}=1.61\right.$. Range: 1.47-1.78). During the period 2003-2006, catches substantially exceeded this level and the stock experienced a rapid decline. Since then, catches have decreased considerably and the 2011 SC estimated that the stock is in good health. The SC once again recommended that catches not exceed 300000 tonnes, which is at the lower end of the range of MSY estimates (ISSF 2012).

A stock assessment of skipjack was conducted for the rst time in 2011. The median estimate of MSY is estimated to be 564000 tonnes (range: 395000 to $843000 \mathrm{t}$ ). The ratio of $\mathrm{F}_{\text {current }} / \mathrm{F}_{\mathrm{MSY}}$ is estimated to be less than 1.0 (the ratio of catch to MSY, used as a proxy for $\mathrm{F}_{\text {current }} / \mathrm{F}_{\mathrm{MSY}}$, is estimated to be $0.81)$. Therefore, overshing is not occurring. The stock is not in an overshed state as spawning biomass is above the $\mathrm{B}_{\mathrm{MSY}}$ level ( $\mathrm{B}_{\text {current }} / \mathrm{B}_{\mathrm{MSY}}=2.56$; Range: 1.09-5.83). In 2011, the SC recommended that catches not exceed 512300 tonnes, the 2005-2009 average (ISSF 2012).

In 2011, the SC conducted a formal stock assessment of the albacore stock for the rst time. The conclusions from the assessment are more pessimistic than what was previously believed on the basis of preliminary analyses that had been conducted in 2008. The ratio of $F_{\text {current }} / \mathrm{F}_{\mathrm{MSY}}$ is estimated to be 1.61 (range: 1.19-2.22). Therefore, overshing is occurring. Piracy in the western tropical Indian Ocean has displaced much of the longline fishing effort to the South and East, which are traditional fishing grounds for albacore. Albacore catches in 2010 were $66 \%$ higher than in 2003. The stock is in an overshed state as spawning biomass is below the $\mathrm{B}_{\mathrm{MSY}}$ level $\left(\mathrm{B}_{\text {current }} / \mathrm{B}_{\mathrm{MSY}}=0.89\right.$; Range: 0.65-1.12). The median estimate of MSY is estimated to be 29900 tonnes (range: 21500 to $33100 \mathrm{t}$ ). It is concluded that the available evidence indicates considerable risk to the stock status at current effort levels (ISSF 2012).

\section{Conservation and Management}

Tunas are like any other renewable living resource; the rate at which they are harvested affects their abundance and their ability to sustain various levels of exploitation. As fishing pressure for tuna increases on a global scale, management and conservation measures are essential if the populations of tunas are to remain at desired levels of abundance. However, the management of tunas is complicated by their migratory nature, and calls for special cooperation among nations, since no one nation can manage tuna effectively. This is reflected in Article 64 of the United Nations Convention on the Law of the Sea, which calls on States to co-operate directly or through appropriate international organizations to ensure the conservation of highly-migratory species. The socio-economic importance of tunas and billfishes coupled with the global spread of industrialized fishing has led to the reduction of global stocks to dangerously low levels (Safina 1998). Recent analyses suggest that large, predatory fishes have declined more than $90 \%$ globally in the past 50 years (Myers and Worm 2003; 2005), raising concerns regarding the future of many species. This is particularly troubling, as any ecosystem-wide effect is bound to be widespread and likely irreversible due to the global nature of the decline (Myers and Worm 2003).

Maritime countries engaged in fishing tuna and tuna like species cooperate regarding conservation and fisheries management within several international frame works (FAO 1994; Marashi 1996). Currently there are five regional fisheries management organizations (RFMOs) dedicated to the conservation and management of tunas viz; (the InterAmerican Tropical Tuna Commission (IATTC), the Western and Central Pacific Fisheries Commission (WCPFC), the International Commission for the Conservation of Atlantic Tunas (ICCAT), the Indian Ocean Tuna Commission (IOTC), and the Commission for the Conservation of Southern 
Bluefin Tuna (CCSBT)), whose common objective is to maintain the populations at or above levels of abundance that can support the maximum sustainable yield (MSY). However, as demand for tuna continues to rise, and with it the levels of exploitation, these organizations find it ever more difficult to reach agreement on the implementation of effective management measures. Cooperation must also extend beyond the scale of single oceans. Industrial tuna fleets are highly mobile and in the principle market tunas are intensively traded on a global scale. In addition many tuna research, conservation and management problems are similar in all oceans. Therefore, there is a need for exchange of information and collaboration on a global scale regarding fisheries for tunas and other species with wide global distribution.

\section{Major issues in tuna fishery in Indian Ocean}

Tuna is an important but not well managed fishery in the Indian Ocean. The evolution of tuna longline fisheries in all oceans has changed fishing strategies as different species have been targeted. These tactics increase the use of longliners, simultaneously making the stock seem bigger but damaging the fish's breeding capacity (Botsford et al. 1997). The present study represents an attempt to generate the main fishery interactions issues in the Indian Ocean as they appear on the basis of the present knowledge we have of the fisheries for tuna and tuna-like species. Severe overfishing leads to species ecological extinction because overfished populations no longer interact significantly with other species in the community (Jackson et al. 2001). Periodic reassessment of the tuna potential is also required with adequate inputs from exploratory surveys as well as commercial landings and this may prevent any unsustainable trends in the development of the tuna fishing industry in the Indian Ocean.

As many fisheries in the region continue to be open access, i.e. no effective controls are in place to limit the growth of fishing capacity and fishing efforts or to limit catches through a quota regime, the high resource rent potential manifests itself initially in high returns to the owners of fishing vessels. This high profitability attracts new entrants into the fisheries as well inciting current operators to invest in technological improvements of fishing craft and gear, causing the fishing power to augment. The capacity and effort of expanding investments commonly continue to take place until the time when the fishery becomes unprofitable and crew incomes have dropped to a low level.

The economic incentive regarding fisheries resources to be found in these deeper waters, combined with insufficient monitoring, control and surveillance of fishing activities has led to a proliferation of Illegal, Unregulated and Unreported fishing (IUU). IUU fishing activities are now one of the biggest threats to Indian Ocean resources and ecosystems. However, IUU fishing is a pervasive problem in many of the world's oceans (Edson 1996). Whereas IUU fishing occurs, or has the potential to occur, in all captured fisheries, both in marine and inland waters, it has raised particular concern with regard to fisheries on the high seas for highly migratory and straddling fish stocks as well as pure highseas stocks, i.e. fishery resources whose entire life cycle is within waters outside of national jurisdictions (Doulman 2000). The IOTC estimated that, in 1996, IUU fishing amounted to nearly $100,000 \mathrm{t}$ in the Indian Ocean, i.e., 10 per cent of all reported landings of tuna and tuna-like species. It is estimated that the lower and upper estimates of the total value of current IUU losses worldwide are between $\$ 10$ billion and \$23.5 billion annually, representing between 11 and 26 million tonnes in fish catch.

The Indian Ocean Tuna Commission (IOTC), responsible for the management of tuna and tuna like fishes of the Indian Ocean, began operations in 1996. Data are provided by member countries, and scientific investigations are coordinated through a scientific committee, comprised of scientists from member countries. There are a number of important issues that the IOTC will need to address if the tuna and bycatch species are to be managed effectively. The present study represents an attempt to examine the main fishery interaction concerned with the tuna fisheries issues in the Indian Ocean as well as the Indian seas. These include, (i) lack of reliable information on the status of stock position of tunas, (ii) lack of information on tuna migration, (iii) lack of trained man power in manning tuna longliners and high sea purseiners (iv) investors are reluctant to invest in high sea tuna fishing as they are still not convinced whether it is a profitable venture (v) permitting foreign tuna fishing vessels to operate in the Indian Ocean countries under the LOP (vi) fisherman are not familiar with the modern post-harvest handling procedures for high priced Sashimi grade tuna, (vii) countries yet to develop satellite based PFZ advisories for oceanic tuna to help tuna vessel operators to save energy and scouting time, (viii) no proper 
deep sea fishing policy/ guidelines, (ix) The El Nino Southern Oscillation (ENSO) phenomenon is considered the main cause for inter annual climatic variability around the globe. There is a lack of studies on oceanographic environmental parameters variability during extreme climatic events (El Nino and La Nina) and its relationship with tuna catch in Indian Ocean. We have presented major issues responsible for declines in many coastal and oceanic tunas over a short period. Our results indicate that tuna should be given serious attention similar to that given to other threatened large marine predators.

Fishing capacity: Studies have indicated overcapacity exists in the purse-seine fishery in the Indian Ocean. In an effort to address this problem, several measures have been approved calling on states to not exceed the number of vessels they had fishing at earlier times, but they have had limited success in controlling fleet growth (ISSF 2011).

Compliance: The IOTC has implemented a number of measures to improve compliance with conservation measures. However, many of the nations do not provide the information needed to monitor compliance.

Database: The IOTC lacks catch-statistical data for some of the important fisheries in the Indian Ocean, which hinders its ability to make comprehensive stock assessments, timely conservation and management recommendations, and to monitor compliance. Data on discards and bycatches are also lacking.

IUU fishing: The IOTC has introduced a number of measures to control IUU fishing, but few of these have been implemented by member nations.

Insufficient financial resources: Field research is needed to improve estimates of vital parameters for tunas, such as the rates of natural mortality, fishing mortality, migration, and mixing. Large-scale tagging programs are useful for this, but they are costly. The IOTC budget is insufficient for such programs, so there is a strong need to seek funding from other sources.

Bycatches: The very complex issue of bycatches in fishery is of great concern to governments and stakeholders. Any measures to deal with this issue must be based on sound science if they are to be effective in reducing bycatches and maintaining sustainable fisheries (ISSF 2011). Obtaining the data needed to quantify the impact of bycatches on the various species will entail expanding observer programs to longline fleets, and require scientific studies of the ecosystem to which the bycatch species and tunas belong and research into the development of fishing gear and technology that will allow the target species to be caught without harming the bycatch species. All of this will require considerable resources, both human and financial. There are several questions that need to be considered under this heading.

a) What are the levels of populations? Are the populations increasing, remaining stable, or decreasing?

b) Are any of the populations in danger of extinction?

\section{Tuna fishery management approaches}

Virtually all human activities have some impact on the ecosystem in which they take place, and fishing is no exception. Management strategies must be adopted for Indian Ocean Tuna stocks (ISSF 2011, 2012).

\section{These strategies should include the following elements}

a. Species-specific management objectives; procedures for data collection, verification and analysis.

b. Precautionary limit and target reference points reflecting international best practice; where necessary, rebuilding programmes aimed at returning stocks to sustainable levels within biologically reasonable time-frames.

c. The harvest is managed in a way that avoids, or at least minimizes, the loss of genetic diversity;

$\mathrm{d}$. The waste of resources is kept at a minimum - low [by catch of target species/catch] ratio;

e. The use of the energy by the vessels is minimized - low [energy use/catch] ratio;

$\mathrm{f}$. The gear used is the best to harvest the resource with the least impact on the habitat - low [habitat damage/catch] ratio.

From the ecological point of view, a fishery should operate in such a way that it meets or approaches the conditions stated before. This view does not include economic or social considerations, which may also be important to humans. For example, yields less than the maximum possible may be preferable if the value of this fish caught or the employment of fisher's increases, but larger catches increase employment in the processing plants (Hall 1998).

\section{By catch management}

Bycatch of juvenile tunas and unmarketable species and size groups of other fish in purse seine fisheries, and juvenile swordfish in longline fisheries, contributes to the overexploitation of some stocks, and is an allocation issue. There has been substantial progress in identifying gear technology solutions to seabird and sea turtle bycatch on 
longlines and to direct dolphin mortality in purse seines (Gilman 2011). The magnitude of incidentally caught species (by-catch), their discards as well as catch of small individuals of target species and the status of stocks of the by-catch species have been another area of concern (Alverson et al. 1994; Hall 1998). Generally, by-catches of tuna fisheries are relatively low. However, they include species of dolphins, turtles, seabirds and sharks, which receive particularly high attention from the international community. In future, a greater utilization of by-catch species may be expected. (1) Fishing may become more selective through gear modifications and changes in fishing areas and seasons. Also, more research is likely to be undertaken to determine the status of stocks of species incidentally caught. (2) Conservation and management measures for sharks must be reviewed to ensure that they are comprehensive; that they provide specific protection to the most vulnerable species and that the ratios of fins to carcass weight are meaningful. (3) Bycatch mitigation measures for seabirds should be based on the current best practice approach adopted by the IOTC 2010. (4) IOTC members must continue research to confirm the effectiveness of sea turtle mitigation measures, taking into account the impact of such measures on the catch of other species.

\section{Structure and process}

The structure and charter of advisory bodies must reflect the adoption of an ecosystem approach to management. Decision-making processes of the Commissions must be reviewed to maximize the likelihood that appropriate conservation and management measures will be agreed and adhered to. The basis upon which fishing rights will be allocated amongst members and co-operating non-members and a process for accommodating the interests of new members must be developed as a priority. Mechanisms to maximize opportunities for sharing of data and research and for harmonization of conservation and management measures across IOTCs must be formalized and improved. Documentation schemes for tuna must cover all components of the catch rather than only product entering international trade.

Tuna fisheries management to date has often been ineffective, it focus on maximizing the catch of a single target species and often ignores habitat, predators and prey of the target species and other ecosystem components and interaction. To address the critical need for more effective and holistic management approach a variety of advisory panels have recommended ecosystem considerations be considered broadly and consistently in managing sustainable fisheries. The overall objective of conservation and management approach is to sustain healthy marine ecosystem and the fisheries.

In particular tuna conservation and fishery management should include the following (a) early warning signs of pressure on the stock of major species -albacore, bigeye and yellowfin catches should not exceed the MSY level, (b) high seas drift gillnetting should be banned and FAD associated -fishing should be regulated, (c) annual species - wise stock assessment to be made, (d) the number of hooks and length of line to be regulated in longline fishing, (e) introduction of large meshed purse- seine for high sea tuna fishing, (f) capture based culture of tuna should be regulated / banned, (g) countries operating their vessels under Letter of Permission (LOP) agreement for tuna fishing should report their catches to the native country, (h) Illegal unreported unregulated (IUU) fishing in Indian Ocean waters by other countries should be banned, (i) tagging experiments for skipjack and yellowfin in the Indian Ocean waters should be undertaken, (j) ensure constant supply of high quality raw material and enable optimum utilization of the capacity of Indian processing plants, (k) provide essential support for training and research, The development of new deep sea fishing policy will be a major step forward in efforts to halt the global decline of yellowfin, skipjack, albacore, bigeye and other tropical tuna species.

\section{What can be done to improve stock assessment inputs to management?}

i. Catch per unit effort series and other data

- Increased scientific observer coverage will improve accuracy

- Need to account for changes in species, size targeting

- Need more scientific sampling to obtain more accurate estimates of growth and aging and expand tag release and recapture experiments should be increased

- Need to explore interactions between seasonal migrations of tuna, stock structure and historic shifts in effort distribution

\section{ii. Need further research on}

- Decision rules for annual quota and other regulations

- Improved spatial resolution in stock assessment models to account for seasonal migrations and stock mixing - Provide essential support for training and research of tuna scientists, more closely follow scientific advice. 
- Put more resources into enforcement and find ways to give industry incentives to harvest sustainably.

\section{iii. Conservation, protection and sustainable management}

- Poverty alleviation and the provision of supplementary livelihood among municipal fisher folk, improvement of productivity of aquaculture within ecological limits;

- Optimal utilization of off-shore, and deep-sea resources and upgrading of post-harvest and value addition technology. - Good networks and strong relationships with sellers and importers also play an important role.

Developing Indian Ocean states were rightly upset about the failure to pass this significant bycatch measure as it is a food security issue for them, if it is good enough for fisheries in the Atlantic Ocean, why isn't it good enough for fisheries in the Indian Ocean. Traditionally, the bulk of the albacore, bigeye, and yellowfin tuna catch have been taken by longliners targeting adults of the species. These fish attain very high prices on sashimi markets and despite declining stocks it remains profitable for operators to continue to fish. Lack of experienced labor for distant - water tuna vessel operation, high cost of production, increasing influence of imports on pricing of tuna in domestic markets, and a sharp decline in landings by its own feet.

Without adequate fisheries management, future catches of some species may decline in the long term due to over fishing. With the present status of stocks, the catches of principal market tunas should not increase on a global scale in the near future unless future technological developments will allow increasing catches of skipjack without increasing those of bigeye and yellowfin. Furthermore, previous studies (Worm et al. 2005) have indicated that species richness, when considered in conjunction with species density, finescale information regarding habitat use, spawning areas, migration patterns, and fishing mortality could be useful in identifying priority areas for marine conservation. We believe the fish are there and they will not stay permanently down, so when the preferred climatic conditions and temperatures improve they will move higher up where fisherman can catch them.

\section{Acknowledgement}

Author thanks the Indian Council of Agricultural Research, New Delhi, Government of India for the award of Emeritus Scientist Scheme and for the financial support to conduct this study. The authors thank the Director, Central Marine Fisheries Research Institute, Kochi, for providing necessary facilities.

\section{References}

Abdussamad EM, Koya KPS, Ghosh S, Rohit P, Joshi KK, Manojkumar B, Prakasan D, Kemparaju S, Elayath MNK, Dhokia HK, Manju S, Bineesh KK (2012) Fishery, biology and population characteristics of longtail tuna, Thunnus tonggol (Bleeker, 1851) caught along the Indian coast. Indian J Fish 59(2):7-16

Adam MS, Anderson RC (1996). Yellowfin tuna (Thunnus albacores) in the Maldives. The Maldivian Tuna Fishery: A collection of Tuna Resource Research Papers, Maldives Marine Research Bulletin 2:23-39

Alverson DL, Freeberg MH, Pope JG, Murawski SA (1994) A global assessment of fisheries by-catch and discards. FAO, Rome, FAO Fisheries Technical Paper, No. 339, 233 p

Anrose A, Kar AB (2010) Some Aspects of the biology of bigeye Tuna (Thunnus obesus, Lowe 1839). In: Andaman and Nicobar Waters, IOTC-2010-WPTT-41, pp 1-17

Bertrand A, Bard FX, Josse E (2002) Tuna food habits related to the micronekton distribution in French Polynesia. Mar Biol 140:1023-1037

Block BA, Dewar H, Blackwell S.B, Williams TD, Prince ED, Farwell CJ, Boustany A, Teo SLH, Seitz A, Walli A, Fudge D (2001) Migratory movements, depth preferences, and thermal biology of Atlantic bluefin tuna. Science 293:1310-1314

Botsford LW, Castilla JC, Peterson CH (1997) The management of fisheries and marine ecosystems. Science 277:509-515

Bromhead D, Foster J, Attard R, Findlay J. Kalish J (2003) A Review of the Impact of Fish Aggregating Devices (FADs) on Tuna Fisheries. Final Report to the Fisheries Resources Research Fund, Bureau of Rural Sciences, Canberra

Chang SK, Liu HC, Hsu CC (1993) Estimation of vital parameters for Indian albacore through length frequency data. J Fish Soc Taiwan 20(1):1-17

Cheung WWL, Close C, Kearney K, Lam V, Sarmiento J, Watson R, Pauly D (2009) Projections of global marine biodiversity impacts under climate change scenarios. Fish Fish 10:235-251

Davis TLO, Farley JH (2001) Size distribution of southern bluen tuna (Thunnus maccoyii) by depth on their spawning ground. Fish Bull 99:381-386

Dayaratne P, De Silva JD (1991) Recent trends in Fisheries for small tunas in Sri Lanka. Collective volume of working document No. 4. Indo-Pacific Tuna Development and Management Perogramme

de Vlaming VL (1983) Oocyte development patterns and hormonal involvements among teleosts. In: Rankin JC, Pitcher TJ, Duggan R (eds) Control Processes in Fish Physiology. Wiley, 
New York, pp 176-199

Dissanayake DCT, Samaraweera EKV, Amarasiri C (2008) Fishery and feeding habits of yellowfin tuna (Thunnus albacares) targeted by coastal tuna longlining in the north western and north eastern coasts of Sri Lanka. Sri Lanka J Aquat Sci 13:1-21

Doulman D (2000) Illegal, Unreported and Unregulated Fishing: Mandate for an International Plan of Action. Paper submitted to the Expert Consultation on IUU Fishing, Sydney, Australia, 15-19 May 2000

Edeson WR (1996) The Code of Conduct for Responsible Fisheries: An Introduction. Int J Mari Coast Law 11(2):97-102

FAO (1993) Fisheries Series No. 40. Fisheries Statistics Series No. $111,72 \mathrm{p}$

FAO (1994) Report of the Ad hoc Consultation on the Role of Regional Fishery Agencies in Relation to High Seas Fishery Statistics. FAO, Rome, FAO Fisheries Report No. 500, pp 167

FAO (2008) FISHSTAT Plus. Universal software for fishery statistical time series, Version 2.3. FAO Fisheries Department, Fishery Information, Data and Statistics Unit

FAO (2009) The state of world fisheries and aquaculture 2008. FAO, Rome

Farley JH, Clear NP, Leroy B, Davis TLO, Mcpherson G (2003) Age and growth of bigeye tuna (Thunnus obesus) from the eastern and western AFZ. CSIRO Marine Research, Tamania, Austrailia, Report No. 2000/100, pp 93

Farley JH, Clear NP, Leroy B, Davis TLO, McPherson G (2006) Age, growth and preliminary estimates of maturity of bigeye tuna, Thunnus obesus, in the Australian region. Mar Freshw Res 57:713-724

Fonteneau A (2002) Estimated sex ratio of large yellowfin taken by purse seiners in the indian ocean; comparison with other oceans iotc Proceedings. pp 279-281

Ghosh S, Pillai NGK, Dhokia HK (2010) Fishery, population characteristics and yield estimates of coastal tunas at Veraval. Indian J Fish 57(2):7-13

Ghosh S, Sivadas M, Abdussamad EM, Rohit P, Koya KPS, Joshi KK, Anuleksmi C, Muthu Rathinam M, Prakasan D, Manju S (2012) Fishery, population dynamics and stock structure of frigate tuna Auxis thazard (Lacepede, 1800) exploited from Indian waters. Indian J Fish 59(2):95-100

Gilman E (2011) Bycatch governance and best practice mitigation technology in global tuna fisheries. Mar Policy 35(5):590-609

Gopakumar G, Ajithkumar TT (1993) Fishery and population characteristics of the bullet tuna, Auxis rochei along South Kerala coast. In: Proceedings of Tuna Meet - 2003, Fishery Survey of India, Mumbai, pp 64-72

Grande M, Murua H, Zudaire I, Korta M (2010) Spawning activity and batch fecundity of skipjack, Katsuwonus pelamis, in the Western Indian Ocean. Working paper presented to the 12th session of the IOTC Working Party on Tropical Tunas. IOTC-2010WPTT12-47
Griffiths SP, Fry GC, Manson FJ, Pillans RD (2007) Feeding dynamics, consumption rates and daily ration of longtail tuna (Thunnus tonggol) in Australian waters, with emphasis on the consumption of commercially important prawns. Mar Freshw Res 58:376-397

Griffiths SP, Kuhnert PM, Fry GF, Manson FJ (2009) Temporal and size-related variation in the diet, consumption rate, and daily ration of mackerel tuna (Euthynnus affinis) in neritic waters of eastern Australia. ICES J Mar Sci 66:720-733

Hafiz A (1985) Skipjack fishery in the Maldives. In: IPTP Coll Vol Work Docs, pp 1-20

Hafiz A (1986) Skipjack fishery in the Maldives. In: IPTP Coll Vol Work Docs, pp 11-22

Hall MA (1998) An ecological view of the tuna dolphin problem. Rev Fish Biol Fish 8:1-34

Hampton J, Gunn J (1998) Exploitation and movements of yellowfin tuna (Thunnus albacares) and bigeye tuna (Thunnus obesus) tagged in the north-western Coral Sea. Mar Freshw Res 49: 475-489

Hernandez-Garcia V (1995) The diet of the swordsh Xiphias gladius Linnaeus, 1758, in the central east Atlantic, with emphasis on the role of cephalopods. Fish Bull 93:403-411

Herrera M, Pierre L (2010) Status of IOTC Database for tropical tunas. IOTC-2010-WPTT-03, pp 28

Hilborn R, Walters CJ (1992) Quantitative Fisheries Stock Assessment: Choice, Dynamics and Uncertainty. Chapman and Hall, New York, $570 \mathrm{p}$

Hsu CC (1999) The length and weight relationship of Albacore, Thunnus alalunga, from the Indian Ocean. Fish Res 41:87-92

IOTC (2003) Report of the Sixth Session of the Indian Ocean Tuna Commission. Victoria, Seychelles, IOTC-SC-06-03R[E], 83 p

IOTC (2009) Report of the Twelfth Session of the Scientific Committee. Victoria, Seychelles, IOTC-2009-SC-R [E], 190 p

IOTC (2010) Report of the Twelfth Session of the Scientific Committee. Victoria, Seychelles, IOTC-2010-SC-R [E], 75 p

IOTC (2011) Report of the Fifteenth Session of the Indian Ocean Tuna Commission. Colombo, Sri Lanka, IOTC-2011-S15-R[E], $111 \mathrm{p}$

ISSF (2011) Status of the world fisheries for tuna: Management of tuna stock and fisheries. Virginia, USA, ISSF Technical report 2011-A05

ISSF (2012) Status of the world fisheries for tuna: ISSF stock status ratings -2012. Virginia, USA, ISSF Technical report 2012$04 \mathrm{~A}, 89 \mathrm{p}$

IUCN (2011) IUCN Red List of Threatened Species. Version 2011.1. http://www.iucnredlist.org. Accessed 16 Jun 2011

Jackson JBC, Kirby MX, Berger WH, Bjorndal KA, Botsford LW, Bourque BJ, Bradbury R, Cooke R, Erlandson J, Estes JA, Hughes TP, Kidwell S, Lange CB, Lenihan HS, Pandolfi JM, Peterson CH, Steneck RS, Tegner MJ, Warner R (2001) Historical overfishing and the recent collapse of coastal 
ecosystems. Science 293:629-638

James PSBR, Pillai PP, Jayaprakash AA, Yohannan TM, Siraimeetan P, Muthiah C, Gopakumar, G, Pillai NGK, Reuben S, Thiagarajan R, Koya KPS, Kulkarni GM, Somaraju MV, Kurup KN, Sathianandan TV (1992) Stock assessment of tunas from the Indian seas. Indian J Fish 39(3-4):260-277

John ME (1995) Studies on yellowfin tuna, Thunnus albacares (Bonnaterre, 1788) in the Indian Seas. Ph.D. Thesis, University of Mumbai, $258 \mathrm{p}$

John ME, Sudarsan D (1993) Fishery and biology of yellowfin tuna occurring in oceanic fishery in Indian seas. In: Sudarsan D, John ME (eds) Tuna Research in India. Fishery Survey of India, Bombay, pp 39-62

Jones CD, Ortiz M, Judge MT, Prince ED (1999) A review of the cooperative tagging center release and recaptures activities for highly migratory species: 1954 to present. ICCAT, SCRS/98/ 70, Rec Doc Sci 49(3):289-300

Joshi KK, Abdussamad EM, Koya KPS, Sivadas M, Somy K, Prakasan D, Manju S, Beni M, Bineesh KK (2012) Fishery, biology and dynamics of dogtooth tuna, Gymnosarda unicolor (Rüppell, 1838) exploited from Indian seas. Indian J Fish 59(2):75-79

Kahraman AE, Göktürk D, Bozkurt ER, Akaylı T, Karakulak FS (2010) Some reproductive aspects of female bullet tuna, Auxis rochei (Risso), from the Turkish Mediterranean coasts. Afr J Biotechnol 9(40):6813-6818

Kahraman AE, Göktürk D, Karakulak FS (2011) Age and growth of bullet tuna, Auxis rochei (Risso), from the Turkish Mediterranean coasts. Afr J Biotechnol 10(15):3009-3013

Kasim HM, Mohan S (2009) Tuna fishery and stock assessment of component species off Chennai coast. Asian Fish Sci 22(1):245256

Kelleher K (2005) Discards in the world's marine fisheries: An update. FAO, Rome, FAO Fisheries Technical Paper 470

Koido T, Suzuki Z (1989) Main spawning season of yellowfin tuna, Thunnus albacares, in the western tropical Pacific Ocean based on the gonad index. Bull Far Seas Fish Res Lab 26:153-163

Koya KPS, Joshi KK, Abdussamad EM, Rohit P, Sivadas M, Somy K, Ghosh S, Koya M, Dhokia HK, Prakasan D, Koya VAK, Manju S (2012) Fishery, biology and stock structure of skipjack tuna, Katsuwonus pelamis (Linnaeus, 1758) exploited from Indian waters. Indian J Fish 59(2):39-47

Kume S (1962) A note on the artificial fertilization of bigeye tuna, Parathunnus mebachi (Kishinouye). Rep Nankai Reg Fish Res Lab 15:79-84

Lee P, Chen I, Tzeng W (2005) Spatial and temporal distribution patterns of bigeye tuna (Thunnus obesus) in the Indian Ocean. Zool Stud 44:260-270

Mace PM (1994) Relationships between common biological reference points used as thresholds and targets of fisheries management strategies. Can J Fish Aquat Sci 51:110-122
Majkowski J (2005) Tuna and tuna-like species. In: Review of the state of world marine fishery resources. FAO Fisheries Technical Paper, pp 163-174

Maldeniya R (1996) Food consumption of yellown tuna, Thunnus albacares, in Sri Lankan waters. Environ Biol Fish 47:101-107

Marashi SH (1996) Summary Information on the Role of International Fishery and Other Bodies with Regard to the Conservation and Management of Living Resources of the High Seas. FAO, Rome, FAO Fisheries Circular No. 908. pp 104

Marcille J, Stéquert B (1976) Etude préliminaire de la croissance du listao (Katsuwonus pelamis) dans louest de l'océan Indien tropical. Cah ORSTOM Sér Océanogr 14:139-151

Marsac F, Potier M, Peignon C, Lucas V, Dewals P, Fonteneau A, Pianet R, Ménard F (2006) Updated biological parameters for Indian Ocean yellowfin tuna and monitoring of forage fauna of the pelagic ecosystem, based on a routine sampling at the cannery in Seychelles. IOTC Proceeding

Maunder MN, Punt AE (2004) Standardizing catch and effort data: a review of recent approaches. Fish Res 70(2-3):141159

McPherson GR (1991) Reproductive biology of yellowfin tuna in the eastern Australian fishing zone, with special reference to the north-western Coral Sea. Aust J Mar Freshw Res 42:465-477

Mohri ME, Hanamoto E, Masao, Takeuchi S (1997) Distribution of bigeye tuna in the Indian Ocean as seen from tuna longline catches. Bull Jap Soc Fish Ocean 61(1):10-17

Morita Y (1973) Conversion factors for estimating live weight from gilled-and-gutted weight of bigeye and yellowfin tunas. Bull Far Seas Fish Res Lab 9:109-122

Murua M, Motos L (2006) Reproductive strategy and spawning activity of the European hake Merluccius merluccius (L.) in the Bay of Biscay. Fish Biol 69:1288-1303

Myers RA, Worm B (2003) Rapid worldwide depletion of predatory fish communities. Nature 423:280-283

Nootmorn P (2004) Reproductive Biology of Bigeye tuna in the eastern Indian ocean. WPTTO 04-05, IOTC Proceedings, pp 1-5

Nootmorn PA, Yakoh, Kawises K (2005) Reproductive biology of yellowfin tuna in the eastern Indian Ocean. http://www.iotc. org/files/proceedings/2006/wptt/IOTC-2005-WPTT-14

Okamoto H, Chang SK, Yeh YM, Hsu CC (2004) Standardized Taiwanese longline CPUE for bigeye tuna in the Indian Ocean up to 2002 applying targeting index in the model. IOTC-2004WPTT-10

Olson RJ (1980) Synopsis of biological data on the Southern bluefin tuna Thunnus maccoyi (Castelnau) 1872. In: Bayliff WH (ed) Synopses of biological data on eight spp. of scombroids. IATTC Spl Rep, pp 151-212

Pillai NGK (2010) An Overview of World tuna fisheries. Sea Food Exp J XLI(3):21-29

Pillai NGK, Ganga U (1985) Fishery and biology of tunas in the Indian seas. In: Harvest and Post-harvest Technology of Fish, 
pp 10-35

Pillai PP, Said Koya KP, Pillai NGK, Jayaprakash AA (1993) Fishery and biology of yellowfin tuna occurring in coastal fishery in Indian seas. In: Sudarsan D, John ME (eds) Tuna Research in India. Fishery Survey of India. Bombay, pp 23-38

Polacheck T (2006) Tuna longline catch rates in the Indian Ocean: Did industrial fishing result in a $90 \%$ rapid decline in the abundance of large predatory species? Mar Policy 30:470-482

Potier M, Marsac F, Cherel Y, Lucas V, Sabatie' R, Maury O, Menard $\mathrm{F}$ (2007) Forage fauna in the diet of three large pelagic shes (lancetsh, swordsh and yellown tuna) in the western equatorial Indian Ocean. Fish Res 83:60-72

Potier M, Marsac F, Lucas V, Sabatie R, Hallier JP, Menard F (2004) Feeding partitioning among Tuna taken in surface and midwater layers: the case of yellown (Thunnus albacares) and bigeye (T. obesus) in the western tropical Indian Ocean. Western Indian Ocean J Mar Sci 3:51-62

Quinn TJ, Deriso RB (1999) Quantitative Fish Dynamics. Oxford Univ Press, New York

Roger C (1994) Relationships among yellown and skipjack tuna, their prey- sh and plankton in the tropical western Indian Ocean. Fish Oceanogr 3:133-141

Rohit P, Rammohan K (2009) Fishery and Biological Aspects of Yellowfin Tuna Thunnus albacares along Andhra Coast, India. Asian Fish Sci 22(1):235-244

Rohit P, Rao GS, Rammohan K (2012) Age, growth and population structure of the yellowfin tuna Thunnus albacares (Bonnaterre, 1788) exploited along the east coast of India. Indian J Fish 59(1): $1-6$

Romanov EV (2002) Bycatch in the tuna purse-seine fisheries of the western Indian Ocean. Fish Bull 100(1):90-105

Safina C (1998) Song for the blue ocean. Holt, New York

Schaefer KM(1998) Reproductive biology of yellowfin tuna (Thunnus albacares) in the eastern Pacific Ocean. Int-Am Trop Tuna Comm Bull 21:201-212

Schaefer KM (2001) Reproductive biology of tunas. In: Block BA, Stevens ED (eds) Tuna: Physiology, ecology, and evolution. Academic Press, California, pp 225-270

Sivadas, M, Abdussamad EM, Jasmine S, Rohit P, Koya KPS, Ghosh S, Joshi KK, Dhokia HK, Prakasan D, Bineesh KK (2012) Assessment of the fishery and stock of striped bonito, Sarda orientalis (Temminck and Schlegel, 1844) along Kerala coast with a general description of its fishery from Indian coast. Indian J Fish 59(2):57-61

Sivasubramaniam K (1985) Tunas and their fishery in the EEZs of Maldives and Sri Lanka. BOBP/WP/31, Bay of Bengal Programme (BOBP), Madras

Solovieff BS (1970) Distribution and biology of bigeye tuna in the
Indian Ocean. Rybn Khoz

Stéquert B (2001) Gonadosomatic index and seasonal variations of plasma sex steroids in skipjack tuna (Katsuwonus pelamis) and yellowfin tuna (Thunnus albacares) from the western Indian ocean. Aquat Living Res 14:313-318

Stequert B, Conand F (2004) Age and growth of Bigeye tuna (Thunnus obesus) in the Western Indian Ocean. Cybium 28(2):163-170

Stequert B, Panfili J, Dean JM (1996) Age and growth of yellowfin tuna, Thunnus albacares, from the western Indian Ocean, based on otolith microstructure. Fish Bull 94:124-134

Stequert B, Marsac F (1989) Tropical tuna - surface fisheries in the Indian Ocean. FAO, Rome, FAO Fisheries Technical Paper No 282, pp 238

Stillwell CE, Kohler NE (1985) Food and feeding ecology of the swordsh in the eastern Atlantic with estimates of daily ration. Mar Ecol-Prog Ser 22:239-247

Sun C, Wang W, Yeh S (2005) Reproductive biology of yellowfin tuna in the central and western Pacific Ocean. WCPFC-SC1. BI WP-1

Suzuki Z (1994) A review of the biology and fisheries for yellowfin tuna Thunnus albacares, in western and central Pacific Ocean. FAO, Rome, FAO Fisheries Technical Paper No 336, pp 108-137

Watanabe H (1960) Regional differences in food composition of the tunas and marlins from several oceanic areas. Rep Nankai Reg Fish Res Lab 12:75-85

Watson R, Pauly D (2001) Systematic distortion in world fisheries catch trends. Nature 424:534-536

Worm B, Sandow M, Oschlies A, Lotze HK, Myers RA (2005) Global patterns of predator diversity in the open oceans. Science 309:1365-1369

Young JW, Davis TLO (1990) Feeding ecology of larvae of southern bluefin, albacore and skipjack tunas (Pisces: Scombridae) in the eastern Indian Ocean. Mar Ecol-Prog Ser 61:17-29

Yukinawa M (1987) Report on 1986 research cruise of the R/V ShoyoMaru. Distribution of tunas and bill shes larvae and oceanographic observation in the eastern Indian Ocean JanuaryMarch 1987. Rep Res Div Fish Agency Japan 61:1-100

Yukinawa M, Miyabe N (1984) Report on the 1983 research cruise of the R/V Shoyo-Maru. Distribution of tunas and bill shes and their larvae in the eastern Indian Ocean October-December, 1983. Rep Res Div Fish Agency Japan 58:1-103

Zhu G, Xu L, Zhou Y, Song L (2008) Reproductive biology of yellowfin tuna $T$. albacares in the west-central Indian Ocean. J Ocean Univ China 7:327-332

Zudaire I, Murua H, Grande M, Korta M, Arrizabalaga H, Areso J, Delgado-Molina A (2010) Reproductive biology of yellowfin tuna (Thunnus albacares) inthe Western and Central Indian Ocean. IOTC-2010-WPTT-48, pp 1-25 